\title{
PENAFSIRAN AYAT-AYAT TENTANG AURAT PEREMPUAN MENURUT MUHAMMAD SYAHRUR
}

\author{
Qabila Salsabila, Reza Pahlevi dan Ali Masrur \\ Fakultas Ushuluddin UIN Sunan Gunung Djati Bandung \\ Jl.A.H.Nasution 105 Cibiru Bandung 40614, Indonesia \\ Email: sherlydevani95@gmail.com
}

\begin{abstract}
In the case of closing the aurat Muhammad Syahrur interpreted the very significant aurat boundaries of the other mufassirs and mufaqqih. He has a theory called Nazhariyat al-Hudud or commonly referred to as the limit theory which is divided into two namely the maximum limit (Hadd al'A'la) and the minimum limit (Had al-Adna) by closing the top (al-Juyub al-Ulwiyyah ) and closed the bottom (al-Juyub as-Sufliyah). In answering the above problems, this research uses a type of library research with the method of presenting data in "Descriptive Analysis" by describing how Muhammad Syahrur interpreted the female aurat in surah al-Nūr [24]: 31, al-Ahzāb [33 ]: 59 and al-Ahzāb [33]: 53. With his boundary theory, Muhammad Syahrur tried to apply the verses of the muhkamat al-Qur'an in the reality of life with its limitations. The result of this study is that Syahrur considered the laws contained in the Qur'an is elastic which can be drawn and adapted to the place and the age. In accordance with the sexuality there are three provisions related to clothing for women: 1). Prohibited or not allowed to open (naked) except only her husband, 2). The minimum limitation of women in general, according to him, is to close the lower intimate area (al-Juyub as-Sufliyyah). This section is called a severe aurat (al-'Awrah al-Mughallazah). This part must be covered when faced with the fourteen mentioned in surah an-Nur 31. And close the upper intimate area (alJuyub al-Ulmiyyah), 3). Clothes for activities and socializing, the provision starts from the minimal limit and then adapted to the situation and conditions of the local community. This boundary also has levels until it reaches the limit that shows only the face and both palms. So the consequence of women who reveal part of al-Juyub according to him means he has violated Hudud Allah. Muhammad Syahrur argued that the veil (headscarf) or headgear for him is not included in the principle of Islamic or beliefs of a person, but only following the habits of society in general.
\end{abstract}

\section{Keywords:}

Aurat; Nazhariyat ;al-Hudud ; Muhammad Syahrur.

\begin{abstract}
Abstrak
Pada kasus menutup aurat Muhammad Syahrur menafsirkan batasan aurat yang sangat signifikan dari para mufassir maupun mufaqqih lain. Dia mempunyai teori yang dinamakan Nazhariyat al-Hudud atau biasa disebut dengan teori limit yang terbagi menjadi dua yaitu batas maksimal (Hadd al'A'la) dan batas minimal (Had al-Adna) dengan menutup bagian atas (al-Juyub al-Ulwiyyah) dan menutup bagian bawah (al-Juyub as-Sufliyah). Dalam menjawab permasalahan di atas, penelitian ini menggunakan jenis penelitian kepustakaan (Library Research) dengan metode penyajian data secara "Deskriptif Analysis" dengan menggambarkan bagaimana Muhammad Syahrur menafsirkan tentang aurat perempuan dalam surah al-Nūr [24]: 31, al-Aḥzāb [33]: 59 dan al-Aḥzāb [33]: 53. Dengan teori batasnya, Muhammad Syahrur mencoba untuk menerapkan ayat-ayat muhkamat al-Qur'an dalam realita kehidupan dengan batasan-batasannya.Hasil dari penelitian ini ialah bahwa Syahrur beranggapan hukumhukum yang terdapat dalam al-Qur'an bersifat elastis yang bisa ditarik dan disesuaikan dengan tempat dan zaman. Dalam menurutp aurat ada tiga ketentuan terkait dengan pakaian bagi perempuan:1). Dilarang atau tidak di perbolehkannya terbuka (telanjang) kecuali hanya suaminya, 2). Batasan minimal perempuan secara umum menurutnya adalah menutup daerah intim bawah (al-Juyub as-Sufliyyah). Bagian ini disebut sebagai aurat berat (al-'Awrah al-Mughallazah). Bagian inlah yang harus ditutupi ketika berhadapan dengan orang-orang yang empat belas disebutkan di dalam surah an-Nur 31. Dan menutup daerah intim atas (al-Juyub al-Ulmiyyah), 3). Pakaian untuk aktivitas dan bersosialisasi, ketentuannya berawal dari batas minimal kemudian disesuaikan dengan situasi dan kondisi masyarakat setempat. Batasan ini pun memiliki tingkatan-tingkatan hingga sampainya kepada batas maksimal yang hanya memperlihatkan wajah dan kedua telapak tangan. Maka Konsekuensi perempuan yang menampakkan bagian al-Juyub menurutnya berarti ia telah melanggar Hudud Allah. Muhammad Syahrur berpendapat bahwa jilbab (kerudung) atau tutup kepala baginya bukan termasuk pada prinsip keislaman ataupun keimanan seseorang, melainkan hanya mengikuti kebiasaan masyarakat secara umum.
\end{abstract}




\section{A. Pendahuluan}

Sesungguhnya Allah telah menciptakan kaum perempuan untuk melakukan tugas yang khusus diantaranya memberikan kedamaian bagi seorang suami, mengasuh putera-puterinya, dan mendidik mereka dengan pendidikan islam secara benar. ${ }^{1}$ Wanita adalah salah satu makhluk ciptaan Allah swt yang mulia. Karakteristik wanita berbeda dari laki-laki dalam beberapa hukum misalnya aurat wanita berbeda dengan aurat laki-laki. Wanita memiliki kedudukan yang sangat agung dalam Islam, dan Islam sangat menjaga harkat martabat seorang wanita. Wanita yang mulia dalam Islam adalah wanita muslimah yang solehah. Allah swt berfirman dalam QS.AlNisā[4]: 34:

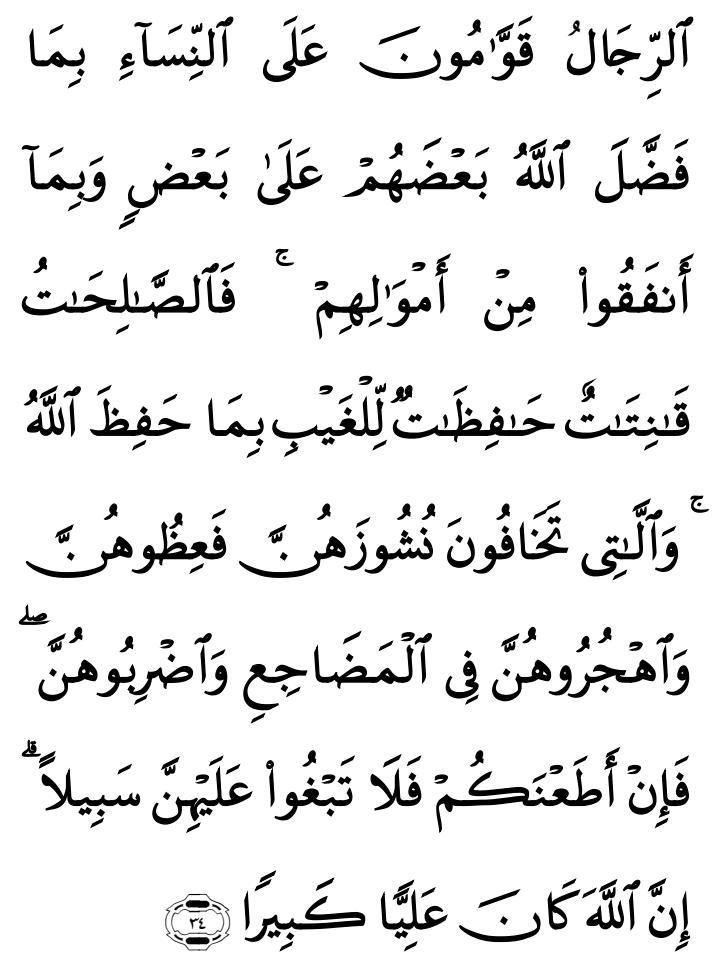

"Kaum laki-laki itu adalah pemimpin bagi kaum wanita, oleh karena Allah telah melebihkan sebagian mereka

1 Mutawalli Al-Sha'rāwi, Fikih perempuan muslimah Busana dan Perhiasan, Penghormatan atas Perempuan, Sampai Wanita Karier. Cet 1. Pnjm Yessi HM. Basyaruddin, (Penerbit Amzah, September 2003), 148. (laki-laki) atas sebagian yang lain (wanita), dan karena mereka (laki-laki) telah menafkahkan sebagian dari harta mereka. Sebab itu maka wanita yang saleh, ialah yang taat kepada Allah lagi memelihara diri ketika suaminya tidak ada, oleh karena Allah telah memelihara (mereka). Wanita-wanita yang kamu khawatirkan nusyuznya, maka nasehatilah mereka dan pisahkanlah mereka di tempat tidur mereka, dan pukullah mereka. Kemudian jika mereka mentaatimu, maka janganlah kamu mencari-cari jalan untuk menyusahkannya. Sesungguhnya Allah Maha Tinggi lagi Maha Besar.'

Wanita solehah adalah puncak kesenangan dunia, sebagaimana sabda Rasulullah sawdalam sebuah hadis dikatakan:

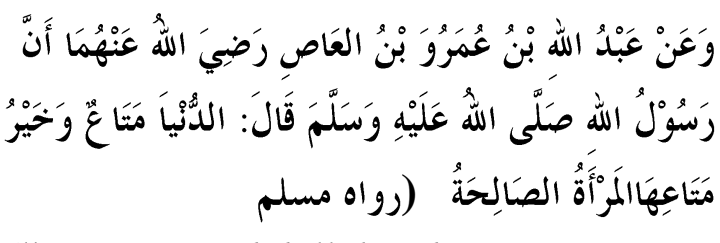

("Dari Abdullah bin Amar ra bahwasanya Rasulullah saw bersabda: Dunia adalah perhiasan, dan sebaikbaiknya perhiasan itu adalah wanita solehah" (HR Muslim). ${ }^{2}$

Hal ini suatu penegasan dari Rasulullah saw bahwa kehadiran seorang wanita solehah dalam sebuah keluarga senantiasa merupakan kesenangan terhadap suami, anak-anak dan semua keluarganya. Hal ini menunjukkan bahwa posisi wanita sangat signifikan atau sangat menentukan baik buruknya sebuah keluarga.

Salah satu isu yang kontroversial dalam diskursus tentang perempuan adalah pembahasan mengenai permasalahan penggunakan hijab bagi perempuan. Hal ini merupakan salah satu dari sekian banyak isu yang menimbulkan pro dan kontra. Masyarakat terbiasa mempergunakan kata "alhijab" untuk menunjukanpakaian perempuan muslim. Padahal, kata ini tidak pernah

\footnotetext{
${ }^{2}$ Hadits sembilan Imam, Riwayat Muslim no.1467 PDF.
} 
disebutkan dalam Alquran maupun asSunnah dalam hubungan laki-laki dan perempuan, kecuali untuk menunjukkan salah satu ciri atau kriteria ummahatul mukminin yaitu sebagai pemuliaan dan penghormatan terhadap kedudukan. Banyak yang beranggapan bahwa menutup aurat akan menjadi faktor kepada kemunduran Islam. Disamping itu, terdapat juga perempuan muslim yang tidak tahu, tidak paham, dan salah paham mengenai cara menutup aurat mengikuti syariat Islam didalam kehidupan sehari-hari. Hukum menutup aurat adalah perkara yang serius dan harus benar-benar diperhatikan. Agar kita sebagai perempuan muslimah tidak terjerumus kedalam kesesatan. ${ }^{3}$

Adanya perbedaan penafsiran para ulama kontemporer pada kasus menutup aurat. Mayoritas ulama tafsir menyatakan bahwa aurat perempuan itu seluruh tubuh kecuali wajah dan telapak tangan. Ada yang mengatakan wajib, ada juga yang mengatakan hanya anjuran, dan bahkan ada yang mengatakan itu tidak wajib. ${ }^{4}$

Berkata Ibnu Qutaibah “Sesungguhnya Allah swt memerintahkan kepada isteri para rasulullah saw untuk memakai hijab, sebab allah memerintahkan kepada kita untuk tidak berbicara dengan mereka kecuali dari balik penutup/tabir ." hal ini merupakan salah satu spesifikasi bagi para isteri Rasulullah saw.Menurut Maududi, perintah-perintah Alquranpada surah alAḥāa ayat 59 mengatakan bahwa meskipun ditunjukkan kepada isteri-isteri Nabi saw, tetapi juga mengikat semua perempuan muslim. ${ }^{5}$

Mutawalli Al-Sa'rāwì mengatakan bahwa busana yang sesuai dengan syariat Islam adalah busana yang dapat menutupi

${ }^{3}$ Muhammad Haitsam Al-Khayyath, Problematika Muslimah Di Era Modern, Pnjm Salafuddin Asmu'i, ( Erlangga, 2009), 130.

${ }^{4}$ Barbara Freyer Stowasser, Reinterpretasi Gender Wanita dalam al-Qur'an, Hadis, dan Tafsir,(Pustaka Hidayah), 332.

${ }^{5}$ Barbara Freyer Stowasser, Reinterpretasi Gender Wanita dalam al-Qur'an, Hadis, dan Tafsir,(Pustaka Hidayah), 332. seluruh tubuhnya, selain wajah dan telapak tangan. Serta diisyaratkan juga agar perempuan tersebut menggunakan pakaian yang tidak sempit, karena pakaian yang sempit dapat membentuk tubuh perempuan, jangan sampai menggunakan pakaian tipis dan menerawang sehingga bagian tubuh perempuan yang berada didalam busana tersebut terlihat. Bahkan seandainya, jika dia merasa khawatir terjadinya fitnah, maka ia diwajibkan memakai penutup wajah dan telapak tangan. ${ }^{6}$

Buku "Risalah Wanita" karya E. Abddurrahman menjelaskan dalam surah AlNūr pada ayat 31 yang memerintahkan bagi perempuan-perempuan yang beriman supaya menahan pandangan, dengan menundukkan kepala dari hal-hal yang dilarang untuk dilihat, kemudian diperintahkan pula agar kaum perempuan menjaga kemaluan mereka dari perbuatan zina yang dapat merusak kehormatan, harga diri, dan keturunan.Selanjutnya mereka diperintahkan agar tidak memperlihatkan perhiasannya kecuali yang biasa nampak dan yang di perbolehkan untuk dilihatnya terbatas pada muka dan kedua telapak tangan. ${ }^{7}$ Oleh sebab itu menutup hiasan dirinya adalah suatu jihad, artinya suatu ibadah yang banyak godaannya.

Menurut Quraish Shihab, perempuan tidak wajib mengenakan jilbab karena jilbab merupakan adat budaya Arab, yang dilakukan karena tradisi bukan karena kewajiban. Menurutnya penggunaan jilbab disesuaikan dengan situasi dan kondisi kebutuhan.Wanita yang menutup seluruh badannya atau kecuali wajah dan telapak tangannya telah menjalankan teks ayat-ayat Alquran bahkan mungkin berlebih. Namun dalam saat yang sama kita tidak wajar menyatakan terhadap mereka yang tidak memakai kerudung, atau menampakkan setengah tangannya, bahwa

\footnotetext{
${ }^{6}$ Mutawalli Al-Sha'rāwi, Fikih Perempuan muslimah Busana dan Perhiasan, Penghormatan atas Perempuan, Sampai Wanita Karier, cet I. Pnjm Yessi HM. Basyaruddin. (Penerbit Amzah, 2003) 28.

${ }^{7}$ E. Abdurrahman, Risalah Wanita, Cet 6, (Bandung, Sinar Baru Algensindo Offest, 2005), 28.
} 
mereka secara pasti telah melanggar petunjuk agama. ${ }^{8}$

Muhammad Sa'id Al-Asmawi juga berpendapat bahwa jilbab itu tidak wajib. Menurutnya jilbab adalah produk budaya Arab. Bahkan ia mengatakan bahwa ayat tentang hijab itu tidak mengandung ketetapaan hukum qat'idan hadis-hadis yang menjadi rujukan tentang kewajiban jilbab atau hijab itu adalah hadis Ahad yang tidak bisa dijadikan landasan hukum tetap. Bila jilbab itu wajib di pakai perempuan, maka dampaknya akan besar. ${ }^{9}$

Begitu juga menurut Qasim Amin dalam tradisi Arab,hijab harus ditegaskan karena ia merupakan bentuk ajaran agama Islam dan memiliki nilai positif bagi pergaulan laki-laki dan perempuan. Namun lima tahun kemudian, pembelaannya tersebut dia bantah sendiri dalam bukunya "Tahrir Al-Mar'ah" menurutnya, hijab hanya tradisi orang Arab dan bukan kewajiban dalam agama Islam. Maka perubahan tradisi berhijab sangat memungkinkan sesuai dengan tuntunan zaman sebagaimana tradisi hijab dalam bangsa Yunani atau Europa. ${ }^{10}$

Muhammad Syahrur berupaya menafsirkan ayat-ayat Alquranpada kasus aurat perempuan dengan menggunakan teori Hudud yang dikenal dengan(Nazhariyat al-Hudud). Ia merumuskan dan menyatakan bahwa batas minimal (Had al-Adna) pakaian perempuan yang berlaku secara umum adalah menutup daerah bagian atas (al-juyub al-'ulwiyah), yaitu daerah payudara dan bawah ketiak, dan juga menutup daerah intim daerah bawah (al-juyub as-sufliyyah). Dan batas maksimal (Had al-A'la). Dalam kaitannya dengan ketentuan aurat sebagaimana dalam

\footnotetext{
${ }^{8}$ M. Quraish Shihab, Tafsir Quraish Shihab, Volume 8, (Jakarta, Lentera Hati, 2009), 534.

${ }^{9}$ Muhammad Said Al-Ashmawy, Haqiqat alHijab wa Hujjiyat Al-Hadith, (Mesir, Madbuli AsShagir, 1995), 16-19.

${ }^{10}$ Nur Lailatul Musyafa'ah, "Pemikiran Fikih Wanita Qasim Amin”, (Jurnal JS GI, Vol 04, No. 01, Agustus 2013 ISSN: 2087-983).
}

hadis Nabi: yaitu seluruh tubuh perempuan kecuali wajah dan kedua telapak tangan.Maka daerah yang termasuk dalam "maa zahara minha" yaitu wajah dan kedua telapak tangan. ${ }^{11}$

Kata Hudud adalah bentuk jamak dari kata hadd. Pada dasarnya had berarti pemisah anatara dua hal atau yang membedakan antara sesuatu dengan yang lain. Secara bahasa hadd berarti cegahan. Sedangkan secara istilah syara'hadd adalah pemberian hukuman dalam rangka hak Allah (ditetapkannya hukuman tersebut demi kemaslahatan masyarakat dan demi terpeliharanya ketentraman/ketertiban umum). Hal ini merupakan sebagian tujuan agama. Oleh karena hukuman itu didasari atas hak Allah. ${ }^{12}$

Penjelasan diatas tentang pendapat para ulama, penulis menemukan penyimpangan pendapat mufassir khususnya Muhammad Syahrur, penulis akan meneliti penafsiran Muhammad Syahrur yang diindikasikan memiliki teori dan argumen yang berbeda dengan mufassir lain dan ulama fiqih. Yang penulis tuangkan

\section{B. HASIL DAN PEMBAHASAN}

1. Aurat Menurut Muhammad Syahrur

a. Pengertian Aurat Menurt Muhammad Syahrur

Muhammad Syahrur memaknai aurat dengan kata al-saw'ah memiliki arti denotatif maupun konotatif. Secara konotatif kata assaw'ah berarti aurat, yaitu bagian tubuh yang tidak boleh dibuka untuk diperlihatkan. Berdasarkan hal ini muncul pendapat bahwa kata tersebut adalah kiasan (kinayah) tentang alat kelamin laki-laki dan perempuan yang jika diperlihatkan akan menganggu pihak lain. Selain itu, kata as-saw'ah juga berarti aib (fadihah) dan bangkai (jifah), seperti dalam firman Allah pada (Qs al-Māidah [5]: 31):

\footnotetext{
${ }^{11}$ Muhammad Syahrur, Epistimologi Qur'an Tafsir Kontemporer ayat-ayat al-Qur'an berbasis Materialisme-DialektikaHistoris, Cet 2. Pnjm M Firdaus. ( Bandung, Penerbit Marja, 2015), 26.

${ }^{12}$ Sayyid Sabiq, Fikih Sunnah 9, Ahli Bahasa Mohammad Nabhan Husein, Cet 20. (Bandung, PT Alma'arif, 2003), 8.
} 


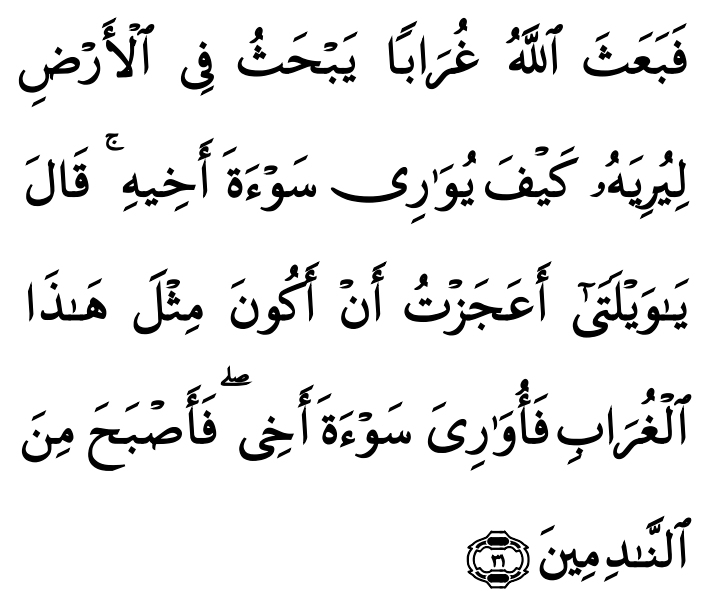

"Kemudian Allah menyuruh seekor burung gagak menggali-gali dibumi untuk memperlihatkan kepadanya (Qabil) bagaimana dia seharusnya menguburkan mayat saudaranya.

Secara denotatif (berkaitan) kata ini berarti keburukan (al-qubh), seperti disebutkan dalam hadits: (perempuan yang buruk rupa namun subur lebih baik dari pada perempuan cantik tapi mandul). Kata ini juga berarti al-baras (bintik-bintik putih pada kulit). Seperti disebut dalam firman Allah pada (QS.Ṭāha [20]: 22):

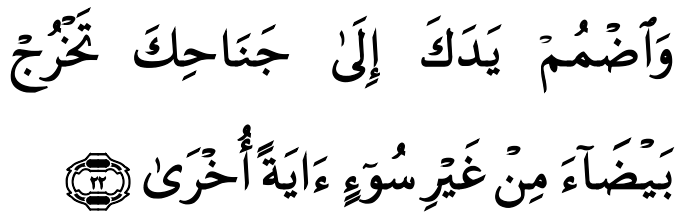

"Dan kepitkanlah tanganmu ke ketiakmu niscaya ia keluar menjadi putih cemerlang tanpa cacat, sebagai mukjizat yang lain (pula)"

Karena rasa berdosa pada seseorang ketika auratnya terbuka merupakan perasaan sosial yang tidak mungkin muncul dalam kondisi sendirian, ketika tidak ada pihak lain yang sengaja melihat dan memperhatikannya.Sebagaimana Ibnu 'Abbas dan Qatadah yang memaknai libas at-taqwa sebagai "amal soleh", maka Syahrur memaknai kata as-saw'ah dengan pengertian "amal buruk" pada diri seseorang yang tidak ingin diekspos kepada pihak lain,apalagi jika orang tersebut adalah golongan yang ahli taubat. Oleh karena itu, ia menegaskan pendapatnya yang telah disebutkan dalam buku al-Kitab wa al-Qur'ān: Qira'āh Mu'asirāh, bahasan tentang al-basar wa il-insān, bahwa ayat fa badat lahuma saw'atuhuma" artinya, maka terlihatlah perbuatan buruk keduanya, bukan kemaluannya. $^{13}$

Muhammad Syahrur mengaitkan makna aurat ini dengan kasus ketika Nabi Adam dan isterinya berada di surga yang mana segala kenikmatan ada disana. Hingga akhirnya mereka membuat kesalahan besar yang dilarang oleh Allah yaitu memakan buah terlarang. Syahrur mengandaikan Nabi Adam dan isterinya sebelum dibujuk oleh setan untuk memakan buah terlarang mereka berada dalam kondisi telanjang di surga. Firman Allah pada Qs al-'A'rāf [7]:19 bahwa: "Tatkala keduanya telah merasai buah kayu itu, nampaklah bagi keduanya aurat-auratnya (badat lahuma sauatahuma), dan mulailah keduanya menutupi dengan daun-daun surga". Menurut Syahrur kata al-Libas dan as-Saw'ah memilki makna majaziakan tetapi pad ayat ini semata-mata menggambarkan kondisi nyata dan tidak mengandung pengertian majazi. Kemudian pada QS.Ṭāha [20]: 118-119 Allah berfirman: "Sesungguhnya kamu tidak akan kelaparan di dalamnya dan tidak akan telanjang, dan sesungguhnya kamu tidak akan merasa dahaga dan tidak pula akan ditimpa panas matahari di dalamnya". Syahrur menafsirkan kata waw dalam kata "wa tafiqa" berfungsi sebagai awal kalimat (al-isti'naf). Di dalam ayat tersebut tidak ada isyarat sedikitpun yang mengarah pada adanya hubungan sebab akibat antara munculnya konsep aurat dan tindakan menutupi tubuh dengan daun surga. ${ }^{14}$

Dalam bahasa Arabkata ('awrah) aadalah segala sesuatu yang jika diperlihatkan, maka seseorang akan merasa malu. Pengertian ini disepakati oleh ahli bahasa Arab dalam

\footnotetext{
${ }^{13}$ Muhammad Syahrur, Metodologi Fiqih Islam Kontemporer, Pnjm. Syahiron Syamsudin, Burhanudin (Yogyakarta, elSaQ Press, 2004), 484-485.

${ }^{14}$ Muhammad Syahrur, Metodologi Fiqih Islam Kontemporer, Pnjm. Syahiron Syamsudin, Burhanudin (Yogyakarta, elSaQ Press, 2004), 486.
} 
memahami kata "aurat". Dari pengertian inilah Nabi menggunakan kata ('awrah) dalam hadis-hadis shahihnya.

Syahrur mengungkapkan Kata ('awrah) ini tidak ada hubungannya dengan masalah halal ataupun haram.Dari hal ini Nabi saw menuturkan jika seseorang memiliki bagian tubuh tertentu yang tidak ingin diketahui oleh orang lain, maka jangan di dumbar.

Kata 'awrah berasal dari konsep rasa malu, yaitu tidak rela seseorang memperlihatkan sesuatu, baik yang ada pada dirinya maupun perilakunya. Rasa malu ini bersifat relatif, dan tidak absolut atau mutlak dan mengikuti tradisi. Ketentuan tentang batasan daerah-daerah intim pada tubuh (al-juyub) bersifat tetap, tapi yang berkaitan dengan aurat dapat berubah-ubah sesuai dengan perkembangan zaman dan tempat. ${ }^{15}$

\section{b. Batasan-batasan Aurat Menurut Muhammad Syahrur}

Aurat dapat dibagi menjadi dua bagian, yaitu aurat yang berat (mughaladzah) dan aurat yang ringan (mukhaffafah). Menurut muhammad Syahur yang dimaksud dengan batasan aurat adalah pertama menahan pandangan (yaghuddu min Absharihim). Menurutnya laki-laki dan perempuan agar untuk tidak saling melihat wilayah yang tidak dikehendaki untuk dilihat, karena misalnya apabila seseorang yang botak bila dilihat oleh orang lain kemudian ia memakai rambut palsu, sebab ia menganggap botak kepalanya sebagai aurat. merasakan malu. Hal ini yang disebut dengan aurat apabila ia merasa malu untuk diperlihatkan maka timbul dosa bagi yang melihatnya. Muhammad Syahrur mengutip hadis rasulullah saw "Barang siapa menutupi aurat mukin, niscaya Allah akan menutupi auratnya."Yang kedua menjaga kemaluannya (Hifz al-faraz). Maksudnya adalah menjaga dari perbuatan zina dari setiap hubungan seksual yang tidak

\footnotetext{
${ }^{15}$ Muhammad Syahrur, al-Kitab wa al-Qur'an Qiro'ah Mu'assiroh, PDF 611.
}

disyari'atkan kecuali terhadap isteri-isteri mereka. Kemudian menjaga kemaluan dari pandangan (bashar). Memandang (al-Bashar) adalah tugas mata yang berbeda dengan proses melihat (an-Nazr) dan menyaksikan (ar$R u$ 'yah) yang terkadang berlangsung di otak tanpa proses memandang terlebih dahulu. Hal ini termasuk dalam kategori batas minimal dalam berpakaian bagi laki-laki. ${ }^{16}$

Adapun batasan aurat perempuan menurut Muhammad Syahrur itu terbagi menjadi dua, pertama bagian tubuh yang terbuka secara alami (qiam al-Zahirah bi al-Khalq) Allah berfirman: "Janganlah mereka menampakkan perhiasan mereka kecuali yang biasa tampak darinya." Dalam ayat ini menjelaskan bahwa dalam tubuh perempuan terdapat perhiasan yang tersembunyi (zinah makfiyyah). Perhiasan yang terbuka secara alami yaitu yang diperlihatkan Allah salam penciptaan tubuh perempuan seperti: kepala, prut, punggung, dua kaki dan dua tangan.

Kedua bagian tubuh yang tidak tampak secara alami (qism ghayr al-Zahir bi alKhalq) yaitu yang disembunyikan oleh Allah dalam bentuk dan susunan tubuh perempuan. Bagian yang tersembunyi ini adalah al-Juyub. $a l-J u y u b$ berasal dari kata ja-ya-ba seperti dalam perkataan jabtu al-Qamisa artinya aku melubangi bagian saku baju. al-Juyub adalah bagian terbuka yang memiliki dua tingkatan, bukan satu tingkatankarena pada dasarnya kata ja-ya-ba berasal dari kata ja-wa-ba yang memilki arti "lubang yang terletak pada sesuatu" dan juga berarti pengembalian perkataan "soal jawab". Istilah juyb pada tubuh perempuan memilki dua tingkatan yang secara rinci berupa: bagian antara dua payudara, bagian bawah payudara, bagian bawah ketiak, kemaluan, dan pantat. Semua bagian ini adalah yang dikategorikan sebagai al-Juyub yang wajib ditutupi oleh kaum perempuan. Dan batas maksimal (Hadd al'A'la) aurat perempuan adalah sebagaiamana hadis nabi saw bahwa seluruh tubuh perempuan adalah aurat kecuali wajah

\footnotetext{
${ }^{16}$ Muhammad Syahrur, al-Kitab wa al-Qur'an Qiro'ah Muassiroh, PDF, 604.
} 
dan kedua telapak tangan yang termasuk dalam kategori "maa zahara minha". ${ }^{17}$

Muhammad Syahrur membagi perhiasan perempuan pada surah AlNūr[24]: 31 yang terbagi menjadi dua yang mana merupakan konsep teori batas dalam berpakaian bagi perempuan. Pertama perhiasan yang nampak (al-zinah alzahirah) kedua perhiasan yang tersembunyi (zinah al-makfiyah). Yang dimaksud ayat ini perhiasan itu ada tiga:

1) Perhiasan yang berwujud benda (zinatul al-Asya') yaitu perhiasan yang berupa penambahan suatu benda ke benda yang lain atau pada suatu tempat untuk memperindahnya. Contohnya: dekorasi disuatu ruangan, desain baju, jepitan rambut, anting, kalung, gelang (hiasan make up bagi wanita) dan lainlain.

2) Perhiasan tempat atau perhiasan lokasi (zinatul mawaqi' auw zinatul makaniyah). Perhiasan ini berupa ruang-ruang publik di daerah perkotaan atau taman-taman hijau yang indah diperkotaan.

3) Perhiasan gabungan antara yang bersifat lokasi dan kebendaan (zinatul makaniyah wa al-Asya) pengertian ini diartikan bahwa perkembangan dan kemajuan ilmu pengetahuan yang memenuhi bumi dengan berbagai bentuk perhiasan lokasi dan hiasan benda. ${ }^{18}$

Syahrur membuat kategori batas minimal dan batas maksimal. Inilah bentuk aplikasi dari teori hudud. Allah tidak menggunakan gaya ungkapan yang bersifat keras dan mengekang, tetapi Allah menggunakan gaya ungkapan yang mendidik agar supaya membentuk generasi muslim dan muslimah yang mempunyai

${ }^{17}$ Muhammad Syahrur, Metodologi Fiqih Islam Kontemporer, Pnjm. Syahiron Syamsudin, Burhanudin (Yogyakarta, elSaQ Press, 2004), 516

${ }^{18}$ Muhammad Syahrur, al-Kitab wa al-Qur'an Qiro'ah Muassiroh, PDF, 606. nilai integrasi tinggi memelihara kesopanan dan menjaga kemaluannya.

2. Dalil-dalil Hukum Tentang Batasan Aurat Perempuan Menurut Muhammad Syahrur

a. Qs Al-Nūr[24]:31 mengenai Pakaian wanita dan laki-laki dalam etika bermasyarakat

Etika berpakaian wanita dan laki-laki terdapat di dua ayat pada Surah Al-Nūr[24] di mulai dari ayat pertama surat Al-Nūr Allah berfirman:

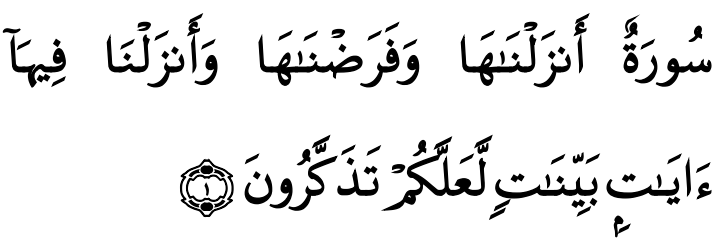

"(sebuah surat yang telah kami turunkan dan Kami wajibkan (menjalankan hukumhukum)nya, dan Kami turunkan di dalamnya tanda-tanda (kebesaran Allah) yang jelas, agar kamu ingat." Qs alNür[24]:1 )

Aturan untuk laki-laki pada Qs alNür[24]:30
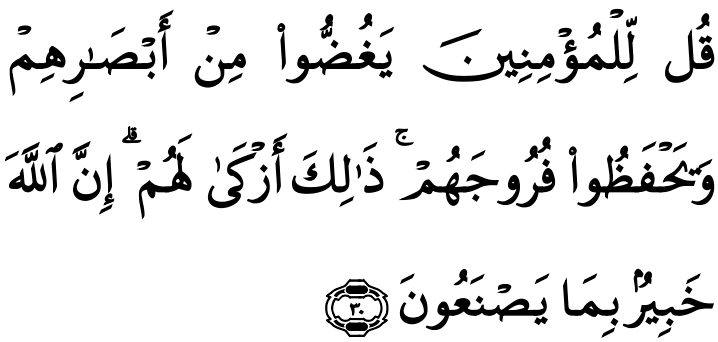

"(Katakanlah kepada laki-laki yang beriman, agar mereka menjaga pandangannya, dan memelihara kemaluannya yang demikian itu, lebih suci bagi mereka. Sungguh, Allah Maha Mengetahui apa yang mereka perbuat. Qs al-Nūr[24]: 30)

Aturan buat wanita pada Qs al-Nūr[24]: 31

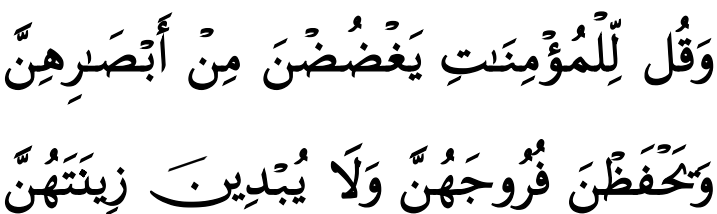



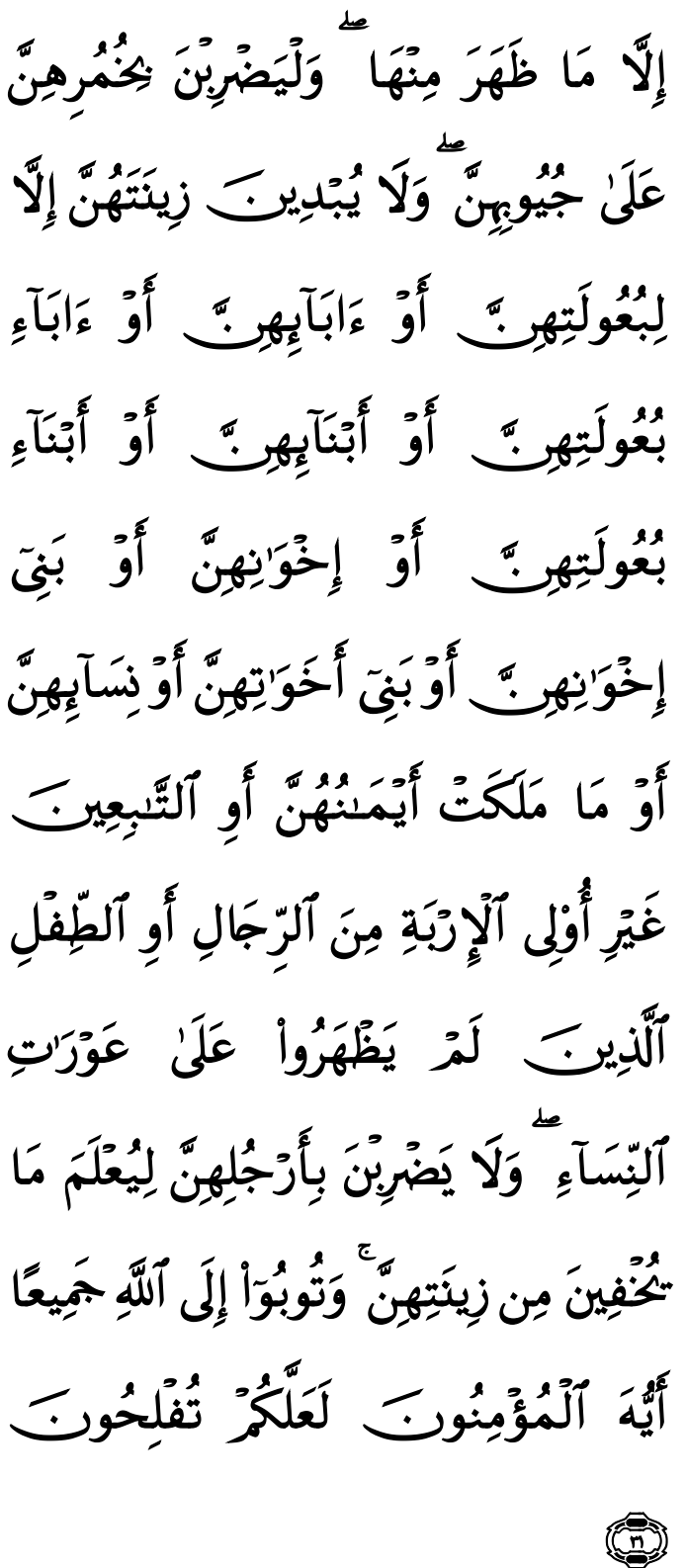

"(Dan katakanlah kepada para perempuan yang beriman, agar mereka menjaga pandangannya, dan memelihara kemaluannya, dan janganlah menampakkan perhiasannya (auratnya), kecuali yang (biasa) terlihat. Dan hendaklah mereka menutupkan kain kerudung ke dadanya, dan janganlah menampakkan perhiasannya (auratnya), kecuali kepada suami mereka, atau ayah mereka, atau ayah suami mereka, atau putra-putra mereka, atau putra-putra suami mereka, atau saudara-saudara laki-laki mereka, atau putra-putra saudara laki-laki mereka, atau putraputra saudara perempuan mereka, atau para perempuan (sesama Islam) mereka, atau hamba sahaya yang mereka miliki, atau para pelayan laki-laki (tua) yang tidak mempunyai keinginan (terhadap perempuan) atau anak-anak yang belum mengerti tentang aurat perempuan. Dan janganlah mereka menghentakkan kakinya agar diketahui perhiasan yang mereka sembunyikan. Dan bertobatlah kamu semua kepada Allah, wahai orangorang yang beriman, agar kamu beruntung. "19

Sebab turunnya ayat ini ada berbagai riwayat yang ditemukan oleh penulis pertama pada riwayat Ibnu Abu Hatim: Asma binti Murtsid pemilik kebun kurma, sering dikunjungi wanita-wanita yang beriman di kebunnya tanpa berpakaian panjang, sehingga kelihatan gelang-gelang kakinya. Demikian juga dada dan sanggul mereka. Maka Asma berkata: "Alangkah buruknya pemandangan ini". Sehubungan dengan itu, maka Allah menurunkan ayat 30 dan 31 sebagai larangan bagi orang-orang beriman membiarkan pandangan mata berkeliaran . hendaklah mereka menahan dan memeliharanya. (HR Ibnu Abi Hatim dari Muqatil dari Jabir bin Abdillah).

Riwayat kedua yang diriwayatkan oleh Ibnu Jarir: Pada suatu waktu ada seorang wanita membuat dua kantong perak yang diisi untaian batu-batu manikam sebagai perhiasan kaki. Apabila ia berjalan disekelompok orang, maka dipukul-pukulkanlah kakinya ketanah sehingga dua gelang kaki itu bersuara. Sehubungan dengan itu maka Allah swt menurunkan ayat ke-31 sebagai larangan memamerkan perhiasan agar mendapat perhatian dari lain jenis. Demikian juga perintah untuk menutup aurat. (HR Ibnu Jarir dari Hadhrami).

Riwayat terakhir dari Syafiyah binti Syaiban pada suatu waktu berada di tempat

${ }^{19}$ Muhammad Syahrur, Al-Kitab wa Al-Qur'an Qiro'ah Muassirah, PDF 604. 
Aisyah isteri Rasulullah saw. Ia menurut tentang wanita Quraisy dengan berbagai keutamannnya. Maka Aisyah berkata: "Wanita Quraisy dalam beberapa hal mempunyai keutamaan dan kelebihan. Namun demi Allah aku melihat wanita Anshar lebih mulia. Sebab mereka sangat mentaati dan jujur terhadap Kitabullah, dan sangat memperhatikan setiap wahyu yang turun". Dialog ini terjadi ketika ayat ke-31 diturunkan yang dilatarbelakangi oleh peristiwa Asma binti Murtsid. (HR Ibnu Abi Hatim dari Syafiyah binti Syaibah). ${ }^{20}$

Muhammad Syahrur mempunyai pemahaman bahwa Allah telah menetapkan sebuah perintah dua hal yang sama tanpa perbedaan antara mukmin-mikminah yaitupertama menundukkan pandangan (galdur bashor).


(Hendaklah mereka menundukkan pandangan mereka) ayat ini terdapat huruf huruf jarr" من" yang bermakna untuk "sebagian" pandangan, maksudnya adalah Allah memerintahkan kita untuk menundukkan sebagian pandangan kita tidak seluruh pandangan, mengenai hal tersebut objek kata kerjanya juga tidak secara langsung disebutkan (menahan pandangan dari apa) dari kata kerja yaghuddu, baik laki-laki ataupun perempuan tanpa ada perbedaan. Redaksi ayat ini menunjukkan bahwa hal ini diserahkan pada tuntunan situasi dan kondisi serta berlaku bagi laki-laki dan perempuan beriman tanpa perbedaan.

Kemudian ayat ini menggunakan kata ghadda yang dalam bahasa Arab menunjukkan arti "perbuatan yang lemah lembut" bukan dengan perbuatan semenamena. Menahan dalam kata ghaddah mengandung pengertian "perlahan dan lemah lembut". Sebagaimana dalam kalimat ghusn ghadd yang berarti "dahan yang lentur tidak kaku". Misalnya jika seorang laki-laki merubah desain pakaiannya

${ }^{20}$ A. Mujab Mahali, Asbabun Nuzul Studi Pendalaman al-Qur'an surah al-Baqarah-an-Nas, (Jakarta, PT RajaGrafindo Persada, 2002), 620. dengan model tertentu yang berbeda dari biasanya dan ia tidak suka jika orang lain melihatnya, meskipun yang melihatnya sesama jenis, sehingga ketika orang-orang melihatnya, maka timbul perasaan tidak enak hati (risih). Sama halnya juga dengan perempuan yang merasa tidak nyaman ketika bagian tertentu dari tubuhnya dilihat oleh orang lain, meskipun yang melihatnya samasama perempuan. Kondisi ini yang dimaksudkan Allah bahwa agar tidak saling melihat wilayah yang tidak dikehendaki untuk dilihat baik bagi laki-laki maupun perempuan. Hal ini disebut sebagai prilaku sosial maksudnya bahwa kita harus mengambil sikap pura-pura tidak tahu (tajahul) seecara sengaja ataupun tidak sengaja apabila melihat wilayah tersebut pada kasus-kasus seperti ini. Contoh inilah yang menurutnya dimaksud dengan kata kerja ghadda.

Perintah kedua yaitu batas minimal pakaian laki-laki menurutnya adalah menutup kemaluan saja (tazkiatutul farji fakot), dan itulah yang dimaksud dengan aturan-aturan atau batasan-batasan yang diberikan Allah.

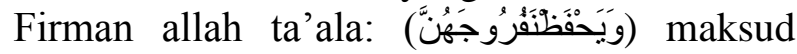
dari ayat ini pertama menjaga nya dari perbuatan zina ketentuan ini dijelaskan pada QS.Al-Mu'min[23]: 4,6 dan 7 "Dan orangorang yang menjaga kemaluannya, kecuali terhadap isteri-isteri mereka atau budak yang mereka miliki, maka sesungguhnya merekadalamhal ini tidak tercela. Barang siapa yang mencari dibalik itu maka mereka tidaklah orang-orang yang melampaui batas". Indikasi yang menunjukkan penjagaan yang dimaksud adalah penjagaan diri dari zina (kecuali terhadap isteri-isteri mereka). Kedua menajaga dari pandangan (bashar) kata ini yang dimaksud dalam surah al-Nūr[24]: 30. Menurutnya memandang adalah tugas mata yangberbeda dari proses melihat, yang terkadang berlangsung diotak tanpa proses memandang terlebih dahulu. ${ }^{21}$

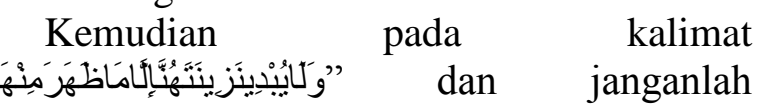

${ }^{21}$ Muhammad Syahrur, al-Kitab wa al-Qur'an Qiro'ah Muassiroh, PDF 604-605. 
menampakkan perhiasannya (aurat), kecuali yang biasa terlihat. Maksud dari potongan ayat ini menurutnya adalah tubuh perempuan dapat terbagi menjadi dua, pertama bagian tubuh yang terbuka secara alami (qism al-Zahirah bi al-Khalq) Allah berfirman: "Janganlah mereka menampakkan perhiasan mereka kecuali yang biasa tampak darinya." Dalam ayat ini menjelaskan bahwa dalam tubuh perempuan terdapat perhiasan yang tersembunyi (zinah makfiyyah). Perhiasan yang terbuka secara alami yaitu yang diperlihatkan Allah dalam penciptaan tubuh perempuan seperti: kepala, perut, punggung, dua kaki dan dua tangan.Kedua bagian tubuh yang tidak tampak secara alami (qism ghayr al-Zahir bi al-Khalq) yaitu yang disembunyikan oleh Allah dalam bentuk dan susunan tubuh perempuan. Bagian yang tersembunyi ini adalah alJuyub.

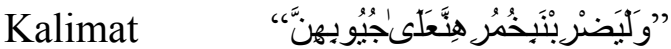
hendaklah mereka menutup kain kerudung ke dadanya. Kata al-Juyub berasal dari kata ja-ya-ba seperti dalam contoh perkataan jabtu al-Qamisa artinya aku melubangi bagian saku baju. al-Juyub adalah bagian terbuka yang memiliki dua tingkatan, bukan satu tingkatankarena pada dasarnya kata ja$y a-b a$ berasal dari kata ja-wa-ba yang memilki arti "lubang yang terletak pada sesuatu" dan juga berarti pengembalian perkataan "soal jawab". Istilah juyb pada tubuh perempuan memiliki dua tingkatan yang secara rinci berupa: bagian antara dua payudara, bagian bawah payudara, bagian bawah ketiak, kemaluan, dan pantat. Semua bagian ini adalah yang dikategorikan sebagai al-Juyub yang wajib ditutupi oleh kaum perempuan. Dan batas maksimal (Hadd al'A'la) aurat perempuan adalah sebagaiamana pada hadis nabi saw bahwa seluruh tubuh perempuan adalah aurat kecuali wajah dan kedua telapak tangan yang termasuk dalam kategori "maa zahara minha". 22

Terdapat tabel pihak-pihak yang termasuk maharim al-nikah dan tabel siapa saja yang berhak untuk melihat perhiasan yang tersembunyi (daerah aurat atas) diantaranya:

\begin{tabular}{|c|c|c|c|}
\hline No & $\begin{array}{c}\text { Daftar } \\
\text { maharim } \\
\text { an-nikah }\end{array}$ & No & $\begin{array}{c}\text { Daftar } \\
\text { orang-orang } \\
\text { yang } \\
\text { sebagian } \\
\text { aurat bagian } \\
\text { atasnya (al- } \\
\text { juyub al- } \\
\text { 'uwliyah) } \\
\text { boleh dilihat } \\
\text { perempuan }\end{array}$ \\
\hline 1 & $\begin{array}{l}\text { Anak Laki- } \\
\text { laki }\end{array}$ & 1 & $\begin{array}{l}\text { Anak Laki- } \\
\text { laki }\end{array}$ \\
\hline 2 & Bapak & 2 & Bapak \\
\hline 3 & $\begin{array}{l}\text { Saudara } \\
\text { Laki-laki }\end{array}$ & 3 & $\begin{array}{l}\text { Saudara } \\
\text { Laki-laki }\end{array}$ \\
\hline 4 & $\begin{array}{l}\text { Paman dari } \\
\text { Bapak }\end{array}$ & & \\
\hline 5 & $\begin{array}{l}\text { Paman dari } \\
\text { Ibu }\end{array}$ & & \\
\hline 6 & Keponakan & 4 & Keponakan \\
\hline 7 & $\begin{array}{l}\text { Anak Laki } \\
\text { Saudara } \\
\text { Perempuan }\end{array}$ & 5 & $\begin{array}{l}\text { Anak Laki } \\
\text { Saudara } \\
\text { Perempuan }\end{array}$ \\
\hline 8 & $\begin{array}{l}\text { Anak } \\
\text { Lelaki } \\
\text { sepersusuan } \\
\end{array}$ & & \\
\hline 9 & $\begin{array}{l}\text { Saudara } \\
\text { Lelaki } \\
\text { sepersusuan }\end{array}$ & & \\
\hline 10 & $\begin{array}{l}\text { Bapak } \\
\text { Mertua }\end{array}$ & 6 & $\begin{array}{l}\text { Bapak } \\
\text { Mertua }\end{array}$ \\
\hline 11 & $\begin{array}{l}\text { Suami dari } \\
\text { Ibu }\end{array}$ & & \\
\hline 12 & $\begin{array}{l}\text { Suami } \\
\text { Anak } \\
\text { Perempuan } \\
\text { (Mantu) } \\
\end{array}$ & & \\
\hline 13 & $\begin{array}{l}\text { Suami } \\
\text { Saudara } \\
\text { Perempuan } \\
\text { (ipar) }\end{array}$ & & \\
\hline
\end{tabular}

${ }^{22}$ Muhammad Syahrur, Metodologi Fiqih Islam Kontemporer, Pnjm. Syahiron Syamsudin, Burhanudin (Yogyakarta, elSaQ Press, 2004), 516. 


\begin{tabular}{|c|c|c|c|}
\hline 14 & $\begin{array}{l}\text { Anak } \\
\text { Lelaki } \\
\text { Suami }\end{array}$ & 7 & $\begin{array}{l}\text { Anak Lelaki } \\
\text { Suami }\end{array}$ \\
\hline & & 8 & $\begin{array}{lr}\text { Di } & \text { tambah } \\
\text { dengan } & \text { yang } \\
\text { tidak } & \text { di } \\
\text { anggap } & \\
\text { sebagai } & \\
\text { muhrim. } & \end{array}$ \\
\hline & & 9 & $\begin{array}{l}\text { Ditambah } \\
\text { dengan } \\
\text { jumlah yang } \\
7 \text { diatas dan } \\
\text { yang } \\
\text { termasuk } \\
\text { kategori } \\
\text { semua pada } \\
\text { kalimat } \\
\text { "nisaaihinna" } \\
\text { (generasi } \\
\text { yang datang } \\
\text { kemudian) } \\
\text { merekalah } \\
\text { yang disebut } \\
\text { garis } \\
\text { keturunan ke } \\
\text { bawah }\end{array}$ \\
\hline
\end{tabular}

Syahrur tidak menyerukan kepada perempuan agar hanya menutup daerah intimnya (aurat berat) saja dan membiarkan bagian lain terbuka di depan delapan orang yang disebutkan diatas. Walaupun terjadi karena lengah atau terpaksa, maka tidak ada yang dihukumi haram akan tetapi hanya sekedar tercela (kurang baik) tapi tidak haram.

Terdapat redaksi ayat yang menjelaskan sejarah pada zaman perbudakan dimasa lalu dimana pihak-pihak perempuan yang diperbolehkan memperlihatkan sebagian dari perhiasannya diantaranya:

1) (أوْمَامَكَكَأَيْنَنَهُنَّنَ) Dalam sejarah, milkalyamin dimaknai sebagai bagian dari perbudakan (riqq) dan perhambaan (al-'ubudiyyah). Jilbab dan hijabtidak diberlakukan pada golongan budak perempuan. Mereka dibiarkan berlalu lalang dijalanan tanpa menutup kepala dan berpakaian dengan bagian dada terbuka. Misalnya pada kasus pernikahan al-misyar (zuwaj al-misyar atau disebut dengan kawin kontrak) ini tidak tergolong perbuatan haram, meskipun pernikahan tersebut tidak dalam arti yang sebenarnya. Menurut Syahrur hal ini dianggap sebagai salah satu wujud milk al-yamin dalam bentuk kontemporer.

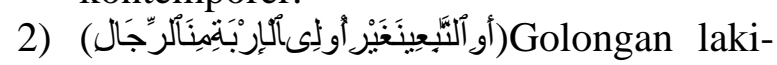
laki pada potongan ayat ini hukumnya mengikuti pihak-pihak yang disebut pada tabel diatas. Yaitu dari laki-laki yang memilki ikatan, bukan yang memilki ikatan persaudaraan. Karena syahwat biologis tidak akan bisa ditahan kecuali misalnya laki-laki yang berprofesi sebagai dokter kandungan ketika membantu persalinan seorang perempuan tentu ia melihat kemaluannya. Dalam menjalani profesinya ia tidak serta merta merasakan dorongan seksual. Dalam kondisi ini posisi dokter tersebut terhadap pasien perempuan adalah diandaikan seperti hubungan antara ayah dan anak perempuannya atau antara ibu dengan anak laki-lakinya. Wajib bagi mukminah memahami hal ini dengan mengetahui bahwa seorang perempuan berhak pergi ke dokter yang dipercayainya dan ia merasa tenang apabila berobat kepadanya, baik menemui dokter laki-laki maupun perempuan tanpa merasa terbebani bahwa hal ini dosa atau haram. Dalam hal ini para dokter tersebut termasuk dalam kategori ghayr uli al-irbati min arrijal.

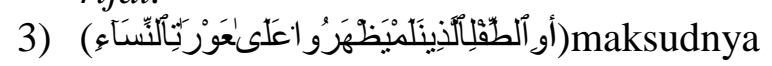
adalah anak-anak yang tidak mengetahui kenapa seorang perempuan merasa malu ketika sedang duduk pada posisi tertentu atau dalam mengenakan pakaian tertentu. Menurutnya hal ini sangat wajar terjadi pada masa anak-anak karena hingga usia tertentu mereka belum mengenal konsep malu. Pemahaman dengan cakupan kategori ayat ini adalah anak-anak yang belum mencapai usia tertentu yang mengkondisikan mereka dalam 
memahami istilah malu dan aib yang dikenal dalam masyarakat. Rasa malu yang dimaksudkan olehnya adalah sebagai bentuk aurat. Kata 'awrah berasal dari konsep rasa malu, yaitu tidak rela seseorang memperlihatkan sesuatu, baik yang ada pada dirinya maupun perilakunya. Rasa malu ini bersifat relatif, dan tidak absolut atau mutlak dan mengikuti tradisi. Ketentuan tentang batasan daerahdaerah intim pada tubuh (al-juyub) bersifat tetap, tapi yang berkaitan dengan aurat dapat berubah-ubah sesuai dengan perkembangan zaman dan tempat. Dan Syahrur mengungkapkan Kata ('awrah) ini tidak ada hubungannya dengan masalah halal ataupun haram ${ }^{23}$ Dalam hal ini bahasa Arab dari kata ('awrah) aadalah segala sesuatu yang jika diperlihatkan, maka seseorang akan merasa malu. Pengertian ini disepakati oleh ahli bahasa Arab dalam memahami kata "aurat". Dari pengertian inilah Nabi menggunakan kata ('awrah) dalam hadis-hadis shahihnya. Dari hal ini Nabi saw menuturkan jika seseorang memiliki bagian tubuh tertentu yang tidak ingin diketahui oleh orang lain, maka jangan di dumbar. ${ }^{24}$

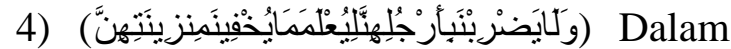
ayat ini gelang kaki yang berlonceng maksudnya wanita tidak boleh untuk memasangnya dan menghentakhentakkan (membunyikan) diatas tanah agar suara lonceng itu tidak terdengar atau memakai sepatu yang tidak mengeluarkan suara ketika dipakaiberjalan. Menurutnya tafsiran ini tidak benar. Pada dasarnya kata 'daraba' merupakan kata dasar yang kemudian dipinjam dan dikembangkan

${ }^{23}$ Muhammad Syahrur, al-Kitab wa al-Qur'an Qiro'ah Mu'assiroh, PDF 612.

${ }^{24}$ Muhammad Syahrur, al-Kitab wa al-Qur'an Qiro'ah Mu'assiroh, PDF 611. oleh katalain. Salah satu derivasi makna kata 'daraba' adalah 'menghentakkan kaki di bumi" bepergian untuk tujuan pekerjaan, perdagangan dan perjalanan, sebagaimana dalam firman Allah surah An-Nisa[4]:94. Sedangkan dalam pengertian perjalanan adalah pada QS.Al-Nisā[4]:101. Dan Qs alMa'idah[5]:106.

Makana kedua dari kata ad-darb adalah bentuk (as-sighah) dan pembuatan/ pembentukan/ menjadikan (as-siyaghah), disebutkan dalam firman Allah: "Kami telah berbuat kepada mereka dan telah Kami berikan kepadamu beberapa perumpamaan?" (Qs Ibrahim [14]:45), firman-Nya: "Dan kami jadikan bagi masing-masing mereka perumpamaan dan masing-masing mereka itu benarbenar telah kami binasakan dengan sehancur-hancurnya" (Qs al-Furqan [25]:39), dan firman-Nya "Sesungguhnya telahkami buat dalam Alquranini segala macam perumpamaan untuk manusia" (QS. Al-Rūm[30]: 58).

Kata darb dipakai dalam berbagai kalimat seperti untuk menyatakan karakter tertentu dan dalam istilah al-sajiyyah aldarbiyah (perangai yang tetap), seakanakan manusia sendiri telah menetapkan perangainya sehingga tidak akan berubah. Kata daraba juga dipakai untuk menyatakan bentuk dari sesuatu benda, seakan-akan membuat perumpamaan lain yang dianggap dapat menyerupainya. Dari pengertian ini muncullah istilah darb almathal (membuat perumpamaan). AdDarbiyah adalah yang dibayarkan kepada seseorang atas jerih payahnya atau sebagai hasil keuntungan dari jual beli atau pengabdiannya pada negara. Kalimat daraba fulanun 'ala yadi fulanin artinya seseorang menghalangi orang lain. Dari sini muncul istilah al-Idrab 'an al- 'amal artinya mengekang diri untuk tidak melakukan suatu pekerjaan, sedangkan istilah al-Idrab 'an at-ta'am berarti mengekang nafsu untuk makan. 
Dari pengertian diatas sebab-sebab larangan dalam redaksi wa yadribu arjuluhunna adalah agar perhiasan yang tersembunyi pada tubuh perempuan, yaitu daerah intimnya (al-juyub), tidak diketahui orang lain. Karena bagian tersebut tidak mungkin nampak kecuali memang perempuan tersebut sengaja menampakkannnya. Allah mencegah perempuan mukminah untuk melakukan suatu pekerjaan yang memperlihatkan sebagian atau seluruh daerah intimnya. Seperti profesi striptease (tari telanjang). Disamping itu juga perempuan tidak boleh melakukan bentuk tarian lain yang memperlihatkan sebagian atau seluruh daerah intimnya.

Allah mengharamkan semua bentuk tarian secara mutlak. Yang diharamkan adalah memperlihatkan daerah intim (meski sebagian saja)secara sengaja. Terbukanya daerah intim perempuan tidak mungkin terjadi selain karena tuntutan pekerjaan untuk mencari nafkah atau karena sedang di daerah pantai. Dalam lingkup batasan hukum (al-hudud) Allah hanya mengaharamkan duamacam profesi bagi perempuan, yaitu bertelanjang (at-ta'riyah) dan pelacuran (al-bigha). Selain dua profesi ini perempuan diperbolehkan untuk memilih dan menjalani sesuai dengan kondisi sosial, ekonomi dan geografi di mana ia hidup yang tidak mengikatnya secra paksa dan permanen. Perempuan yang menjalankan profesi yang bertentangan dengan kebiasaan masyarakatnya hanya akan menerima celaan dari masyarakat dan tidak terkait dengan hukum haram dari agama. $^{25}$

Quraisy Shihab mengatakan yang dimaksud menampakkan perhiasan adalah tubuh perempuan yang dapat merangsang lelaki, kecuali yang biasa tampak atau kecuali yang terlihat tanpa maksud untuk ditampak-tampakkan, seperti wajah dan telapak tangan. Hiasan pokok perempuan

\footnotetext{
${ }^{25}$ Muhammad Syahrur, al-Kitab wa al-Qur'an Qiro'ah Mu'assiroh, PDF, 613.
}

adalah dadanya, dan ayat ini melanjutkan "hendaklah mereka menutup kain kerudung mereka ke dada mereka" dan diperintahkan juga kepada isteri-isteri nabi, "wahai nabi janganlah menampakkan perhiasan, yaitu keindahan tubuh mereka, kecuali kepada suami mereka karena memang salah satu tujuannya perkawinan adalah menikmati hiasan itu, atau ayah mereka karena ayah sedemikian cinta kepada anak-anaknya sehingga tidak mungkin timbul birahi bahkan mereka selalu menjaga kehormatan anakanaknya, atau ayah suami mereka karena kasih sayangnya kepada anaknya menghalangi mereka melakukan yang tidak senonoh kepada menantu-menantunya, atau putra-putra mereka karena anak tidak memiliki birahi terhadap ibunya, atau putra-putra suami mereka yakni anak tiri mereka, karena mereka bagaikan anak apalagi rasa takutnya kepada ayah mereka menghalangi mereka untuk berbuat usil, atau saudara-saudara laki-laki mereka, atau putra-putra saudara laki-laki mereka karena mereka itu bagaikan anak-anak kandung sendiri, atau wanita-wanita mereka, yaitu wanita-wanita yang beragama Islam. Karena mereka wanita dan keislamannya menghalangi mereka menceritakan rahasia tubuh yang dilihatnya kepada orang lain berbeda dengan wanita non-muslim yang bisa jadi mengungkaprahasia keindahan tubuh mereka, atau budak-budak yang mereka miliki, baik laki-laki maupun perempuan, atau yang budak perempuan saja karena wibawa tuannya menghalangi mereka usil, atau pelayanpelayan laki-laki yang tidak mempunyai keinginan hawa nafsu terhadap wanita, seperti orang yang sudah tua renta atau anak-anak yangbelum dewasa karena belum mengerti tentang aurat-aurat wanita sehingga belum memahami teks seks.

Al-Biqā'i mengartikan kata daharaba adalah meletakkan atau memukul sesuatu secara cepat dan sungguh-sungguh. Pemakaian kerudung itu harusnya diletakkan dengan sungguh-sungguh untuk tujuan menutupinya, bahkan huruf $b a$ pada kata $b i$ khumurihinna dipahami oleh sementara ulama berfungsi sebagai al-Ilshā $q$, yakni kesetaraan 
dan ketertempelan. Untuk lebih menekankan lagi agar kerudung tersebut tidak terpisah dari bagian badan yang harus ditutupi. $^{26}$

Al-Maraghi menafsirkan ayat ini dengan beberapa ponit. Pertama bahwa terdapat larangan memandang aurat lakilaki dan aurat wanita yang mereka tidak dihalalkan memandangnya (antara pusar dan lutut). Demikian pula jika memandang selain itu dengan dorongan syahwat, maka hukumnya haram. Kedua perintah memelihara kemaluannya dari perbuatan yang diharamkan seperti zina dan menutupinya agar tidak terlihat. Ketiga ayat ini juga menjelaskan tentang larangan menampakkan perhiasan pada laki-laki asing, kecuali yang biasa tampak dan tidak mungkin disembunyikan, seperti contohnya: cincin, celak mata dan lipstik. Lain halnya jika menampakkanperhiasan yang harus disembunyikan seperti gelang tangan, gelang kaki, kalung, selempang dan anting-anting karena perhiasan tersebut berada pada bagian yang tidak nampak dan yang tidak halal untuk dipandang kecuali orang-orang yang dikecualikan pada ayat ini. $^{27}$

Al-Qurthubi menafsirkan ayat ini dengan menjelaskan bahwa Jangan sampai wanita yang beriman melepaskan pandangan mereka dengan maksud membangkitkan nafsu-nafsu yang tersembunyi pada laki-laki. Jangan sampai mereka menyerahkan kemaluannya melainkan dengan cara halal dan baik yang dapat memenuhi hasrat nafsu dengan suasana yang bersih dan tidak membuat anak-anak yang lahir darinya merasa malu terhadap masyarakat dan kehidupan.

Setiap wanita ingin tampil tetap menawan dan cantik serta berpenampilan cantik di hadapan laki-laki. Dan Islam sama sekali tidak memerangi kesenangan fitrah

\footnotetext{
${ }^{26} \mathrm{M}$ Quraish Shihab, Tafsir al-Misbah (Pesan, Kesan dan Keserasian al-Qur'an), volume 8, cet V (Jakarta, Lentera Hati, 2002), 526-528.

${ }^{27}$ Al-Maraghi, Tafsir Al-Maraghi, Pnjm Anwar Rosyidi dkk, juz 22 (Semarang, Putra Toha), 63-64.
}

ini.Namun ia mengaturnya dan memberi rambu-rambunya serta mengarahkannya agar menampakkannya hanya untuk seorang lakilaki yaitu suaminya, dia berhak melihat apa yang tidak boleh dilihat oleh orang lain.

Kecantikan karena membuka aurat dan tubuh merupakan kecantikan yang bercitra rasa rendah, sedangkan kecantikan yang berkarakter itulah kecantikan suci yang mengangkat apresiasi seseorang terhadap kecantikan, menjadikannya layak dan sesuai bagi manusia. Orang-orang yang bertakwa selalu menjaga diri dari godaan pandangan. Sesungguhnya Allah tidak akan ingin menjerumuskan hati orang-orang yang beriman kepada ujian dan musibah seperti ini. $^{28}$

Al-Qardhawi, Al-Nawawi madzhab syafi'i madzhab Imam maliki, Hambali dan Hanafi mereka sependapat bahwa pada kalimat "janganlah mereka menampakkan perhiasannya kecuali yang biasa tampak darinya"yang dimaksud aurat yang boleh ditampakkan hanya wajah dan kedua telapak tangan.

Dari ayat diatas dapat penulis ketahui bahwa penafsiran Muhammad Syahrur terkait ayat tentang perhiasan wanita pada surah AlNürayat 31 adalah Allah memerintahkan kepada kaum perempuan untuk menutupi auratnya kecuali yang biasa terlihat atau nampak dari kata "maa dzhara minha" yaitu kedua telapak tangan dan wajah. Hal ini senada dengan pendapat para mufassir lain. Dan ini disebut dengan batasan maksimal perempuan atau Syahrur biasa menyebutnya dengan (hadd al-A'la). Sedangkan batas minimal perempuan dari ayat 31 ini adalah Syahrur menafsirkan kata "juyub" dengan mengartikan dua bagian daerah intim yaitu menutupi bagian inti daerah atas (al-Juyub alUlwiyyah) dan menutupi bagian intim bawah (al-Juyub as-Sufliyyah). Yang penulis pahami pada kalimat "hendaklah mereka menutup

\footnotetext{
${ }^{28}$ Sayyid Qutub, Tafsir Fi Zhilalil Qur'an dib bawah naungan al-Qur'an (surat Tahaa 57-An-Naml 81), Jilid 8. Pnjm As'ad Yasin, dkk.( Jakarta, Gema Insani Press, 2004), 234-236.
} 
kain ke dadanya" Pada kasus ini penulis tidak setuju dengan apa yang di tafsirkan oleh Syahrur bahwa orang-orang yang disebutkan pada tabel diatas boleh melihat (al-Juyub al-Ulwiyyah). Pada hakikatnya yang benar-benar boleh melihat dan memandang seluruh tubuh perempuan(isterinya) hanyalah suaminya karena hal tersebut termasuk dalam kehalalan kecuali melihat kemaluannya tanpa keperluan khusus dan hukumnya makruh artinya dibenci Allah karena hal tersebut bertentangan dengan etika dan sopan santun.

Penulis berpendapat sama dengan Syahrur maksud ayat disini dari kata "menahan pandangan"galdhul bashor. Yaitu memandang lawan jenis yang bukan muhrim baik dengan hawa nafsu maupun secara prinsip. Karena indera mata adalah faktor utama yang membuat kita baik dan buruknya apa yang kita pandang. Point kedua dari kata "memlihara kemaluannya" penulis juga sependapat dengan Syahrur maksud dari potongan ayat ini adalah memelihara dari perbuatan keji yaitu berzina misalnya. Hal awal timbul terjadinya zina karena faktor utama yang tidak menahan pandangan lalu timbul hasrat dari hati untuk melakukan hal yang dibenci Allah.

Kalimat "para pelayan laki-laki yang tidak mempunyai keinginan terhadap wanita" Syahrur mengambil contoh dari potongan ayat ini pada pekerjaan dokter. Jika perempuan pergi kedokter laki-laki anggap saja sebagai anak dengan ibunya dan juga sebaliknya. Perempuan sebaiknya berobat kepada dokter perempuan lagi. Jika memang tidak ada dokter perempuan didaerahnya maka harus didampingi oleh suaminya atau mahromnya. Dan diharuskan apabila di daerah tersebut ada dokter yang beragama Islam maka tidak boleh berobat kepada selain dokter tersebut. Hal ini menjaga timbulnya akanfitnah.

Jadi menurutnya aurat adalah sesuatu yang jika membuat seseorang merasa malu apabila terlihat sesuatu. Ada hadis nabi yang berbunyi 'Barang siapa yang menutupi aurat mukmin, niscaya Allah akan menutupi auratnya" dari sini Syahrur mempunyai pemikiran bahwa hadis ini bukan berarti harus menggunakan pakaian agar tidak nampak tapi menurutnya aurat berawal dari rasa malu ketika ketidak sukaan seseorang jika terlihatnya sesuatu. Dan Syahrur tidak mengaitkan masalah aurat ini dengan hukum halal dan haram. Dan pendapat inipun keliru karena jika rasa malu yang menurutnya jadi ukuran, maka totalitas relatifitas penafsiran tidak ada batasannya.

b. QS.Al-Ahzāb [33]: 59 tentang jilbab yang ditunjukkan kepada isteri Rasul dan isteri orang-orang beriman



"Hai Nabi, katakanlah kepada isteriisterimu, anak-anak perempuanmu dan isteri-isteri orang mukmin: "Hendaklah mereka mengulurkan jilbabnya ke seluruh tubuh mereka". Yang demikian itu supaya mereka lebih mudah untuk dikenal, karena itu mereka tidak di ganggu. Dan Allah adalah Maha Pengampun lagi Maha Penyayang."

Asbabun Nuzul

Riwayat pertama, Suatu ketika Siti Saudah, isteri Rasulullah keluar rumah untuk suatu kepentingan setelah turunnya ayat hjab. Ia seorang wanita yang badannya tinggi besar, sehingga mudah dikenal orang. Pada waktu itu Umar bin Khathab melihatnya, dan ia berkata: "Wahai Saudah demi Allah bagaimana kami akan dapat mengenalmu, karena itu, cobalah pikir mengapa kamu keluar?". dengan tergesagesa Saudah segera pulang dan disaat itu 
Rasulullah sedang berada dirumah Aisyah. Beliau sedang memegang tulang waktu makan. Ketika Saudah masuk langsung berkata: "Wahai Rasulullah aku keluar untuk suatu keperluan. Dan Umar menegurku karena masih juga mengenalku". Sehubungan dengan itu, maka Allah menurunkan ayat ke-59 kepada Rasulullah ketika tulang itu masih berada ditangannya. Maka beliau bersabda: "Sesungguhnya Allah telah mengizinkan kamu ke luar untuk suatu keperluan”. (HR Bukhari dari Aisyah).

Riwayat lain ada suatu waktu pernah isteri-isteri Rasulullah ke luar malam hari untuk buang air. Pada waktu itu kaum munafik mengganggunya dan menyakiti. Hal ini diadukan kepada Rasulullah, sehingga beliau menegur orang-orang munafik tersebut. Mereka menjawab: "Kami hanya mengganggu hamba sahaya". Sehubungan dengan itu maka Allah swt menurunkan ayat ke-59 sebagai perintah untuk berjilbab (pakaian tertutup), agar ada perbedaan dengan hamba sahaya. (HR Ibnu Sa'ad dalam kitab At-Thabaqat dari Abi Malik. Ibnu Sa'ad juga meriwayatkan dari Hasan dan Muhammad bin Ka'ab AlQurazhi).

Ketika ayat ke-59 diturunkan, maka wanita-wanitaAnshar keluar dengan menggunakan pakaian yang menutup kepala, sehingga kelihatan aneh dan anggun ketika berjalan. (HR Ibnu Abi Hatim dari Umi Salamah). ${ }^{29}$

Menurut Muhammad Syahrur ayat 59 pada surah Al-Aḥzāb ini masuk kedalam klasifikasi ayat ta'limat (pengajaran/ informasi), bukan sebagai penetapan hukum (tasyri'). Menurutnya hijab adalah kebiasaan budaya Arab sebab pada masa turunnya ayat ini perbudakan masih ada. Kemudian untuk membedakan budak dengan wanita merdeka yaitu dengan menggunakan hijab. Penafsiran Syahrur

${ }^{29}$ A. Mujab Mahali, Asbabun Nuzul Studi Pendalaman AL-Qur'an surah Al-Baqarah-An-Nas, (Jakarta, PT RajaGrafindo Persada, 2002), 691. mengaitkan dengan Asbab Nuzul. Muhammad Syahrur menjelaskan kata jilbab berasal dari kata ja-la-ba dalam bahasa Arab memiliki dua arti kata kerja, yang pertama mendatangkan sesuatu dari satu tempat ke tempat lain. Kedua sesuatu yang menutupi sesuatu yang lain. Misalnya kata jilbab itu sobekan kain yang digunakan untuk menutupi luka sebelum bertambah parah dan bernanah. Dari sini muncul kata kata al-jilbab diartikan sebagai perlindungan yaitu pakaian keluar rumah berupa celana panjang, baju, seragam resmi, mantel dan lain-lain. Pakaian yang dimaksudkan ini menurutnya termasuk dalam kategori al-jalabib.

Perempuan mukminah diwajibkan untuk menutup bagian-bagian tubuhnya, berpakaian ketika keluar dari rumah itu disebut dengan jilbab.Apabila ditampakkan akan menyebabkan adanya gangguan (al-ada). Adapun gangguan ini terbagi menjadi dua macam yaitu yang bersifat alami (at-tabi $\left.{ }^{\prime} i\right)$ dan sosial (al-ijtimấi).

Dalam ayat ini digunakan huruf jarr "min" untuk menunjukkan sebagian dari keseluruhan (at-ta'bid) dan menggunakan kata yudnina yang berfungsi untuk mendekatkan (taqrib). Kata ini berasal dari kata danawayadnu. Kata al-jalb dan al-idna memiliki makna yang serasi. Aktivitas mendekat disebut dengan kata al-jalb. Baju yang tidak bersentuhan dengan tubuh disebut $a d$ dunuww.

Pada kata $f a$ dari ayat ini “an yu'rafna $f a$ lâ yu'dzayna" menunjukkan adanya suatu sebab ( $f a$ sababiyah) dan akibat (ta'qib) anatara pengetahuan dan gangguan. Ini yang disebut dengan (al-adha al-ijtima 'i)

Gangguan alami yang terkait dengan lingkungan geografis, seperti suhu udara dan cuaca. Perempuan seharusnya berpakaian sesuai dengan kondisi suhu dan cuaca yang ada ditempat tinggalnya. Sedangkan gangguan sosial adalah gangguan yang berasal dari masyarakat, akibat pakaian luar yang dipakai oleh perempuan.Karenanya, perempuan hendaklah memakai pakaian luarnya dan beraktifitas sesuai dengan kebiasaan yang berlaku didaerahnya, sehingga tidak menjadi 
sasaran celaan dan gangguan dari orangorang. $^{30}$

Sependapat dengan penafsiran Muhammad Syahrur pada kasus ayat tentang hijab ini, Menurut Maududi, perintah-perintah Alquranpada surah AlAhzāb ayat 59 mengatakan bahwa meskipun ayat ini ditunjukkan kepada isteri-isteri Nabi saw, tetapi juga mengikat semua perempuan muslim. Hukum tentang pakaian Islam (satr atau penutup) termasuk dalam sistem sosial hijab, yang hanya merupakan satu bagian dari beragam karakter masyarakat. ${ }^{31}$

Menurut Qasim Amin dalam tradisi Arab, hijab harus di tegaskan karena ia merupakan bentuk ajaran agama Islam dan memiliki nilai positif bagi pergaulan lakilaki dan perempuan. Namun lima tahun kemudian, pembelaannya tersebut dia bantah sendiri dalam bukunya "Tahrir AlMar'ah". Menurutnya, hijab hanya tradisi orang Arab dan bukan kewajiban dalam agama Islam. Maka perubahan tradisi berhijab sangat memungkinkan sesuai dengan tuntunan zaman sebagaimana tradisi hijab dalam bangsa Yunani atau Europa.

Ia meneliti tentang tinjauan hukum islam terhadap bentuk hijab yang dianjurkan dalam Islam yaitu menutup seluruh tubuh perempuan kecuali wajah dan telapak tangan. Hasil penelitiannya menyimpulkan bahwa tidak terdapat dalam Alqurandan hadis ajaran yang menyatakan bahwa wajah perempuan merupakan aurat sehingga wajahnya harus ditutup. Penutup wajah hanyalah kebiasaan yang kemudian di anggap sebagai ajaran agama islam. Selain itu hijab tidak boleh diartikan sebagai bentuk pemisahan ruang pergaulan antara laki-laki dan perempuan karena tidak ada anjurannya di dalam Alqurandan hadis. Hijab sebagai penutup tubuh perempuan termasuk wajah dan sebagai bentuk

\footnotetext{
${ }^{30}$ Muhammad Syahrur,al-Kitab wa al-Qur'an Qiro'ah Muassiroh, PDF 614.

${ }^{31}$ Barbara Freyer Stowasser, Reinterpretasi Gender Wanita dalam Al-Qur'an, Hadis, dan Tafsir,( Pustaka Hidayah), 332.
}

pemisah ruang lelaki dan perempuan membawa perempuan berkedudukan rendah, menghambat kebebasan, dan pengembangan daya keahlian mereka untuk mencapai kesempurnaan. $^{32}$

Muhammad Sa'id Al-Asmawi juga berpendapat bahwa jilbab itu tidak wajib. Menurutnya jilbab adalah produk budaya Arab. Bahkan ia mengatakan bahwa ayat tentang hijab itu tidak mengandung ketetapaan hukum qat' $i$ dan hadis-hadis yang menjadi rujukan tentang kewajiban jilbab atau hijab itu adalah hadis Ahad yang tidak bisa dijadikan landasan hukum tetap. Bila jilbab itu wajib di pakai perempuan, maka dampaknya akan besar. Seperti dalam kutipannya: "Ungkapan bahwa rambut perempuan adalah aurat karena merupakan mahkota mereka. Setelah itu, nantinya akan di ikuti dengan pernyataan bahwa mukanya, yang merupakan singgasana, juga aurat. Akhirnya perempuan serba aurat." Implikasinya, perempuan tidak bisa melakukan aktifitas apapun sebagai manusia yang diciptakan Allah karena serba aurat. ${ }^{33}$

Lain halnya dengan Al-Qurthubi mengatakan menutup aurat dengan memakai jilbab adalah kewajiban. Menurutnya seluruh tubuh perempuan adalah aurat maka wajib ditutupinya dengan hijab, kecuali wajah dan telapak tangan. Hal ini tidak terlalu dipermasalahkan apabila membuka keduanya dan tidak pula ekstrim jika menutupi keduanya.

Penulis menyimpulkan bahwa terdapat dua pendapat yang berbeda yang mengemukakan masalh hijab. Pendapat pertama bahwa pendapat Sayyid Qutub merujuk pada dalil-dalil Alqurandan asSunnah dengan menyimpulkan bahwa hijab adalah pakaian wajib perempuan muslimah. ${ }^{34}$ Pendapat kedua termasuk pendapat Syahrur

${ }^{32}$ Nur Lailatul Musyafa'ah, "Pemikiran Fikih Wanita Qasim Amin”, Jurnal JS GI, Vol 04, No. 01, Agustus 2013 ISSN: 2087-983.

${ }^{33}$ Muhammad Said al-Ashmawy, Hakikat Hijab wa Hujjiyat al-Hadits, (Mesir, Madbuli as-Shagir, 1995), 16-19.

${ }^{34}$ Sayyid Qutub, Tafsir fi Zhilalil Qur'an, jilid 9. Pnjm As'ad Yasin dkk, (Jakarta, Gema Insani Press, 2004), 289. 
yang mengemukakan pendaptanya tidak pada kaidah keagamaan dan dalil-dalil dalam Alquranmaupun as-Sunnah. Jikapun ada pasti lebih cenderung liberal dan mengungkapkan bahwa hijab hanyalah aspek kebudayaan.

c. QS.Al-Ahzāb [33]:53 tentang hijab yang secara terbatas terkait dengan para isteri Rasul

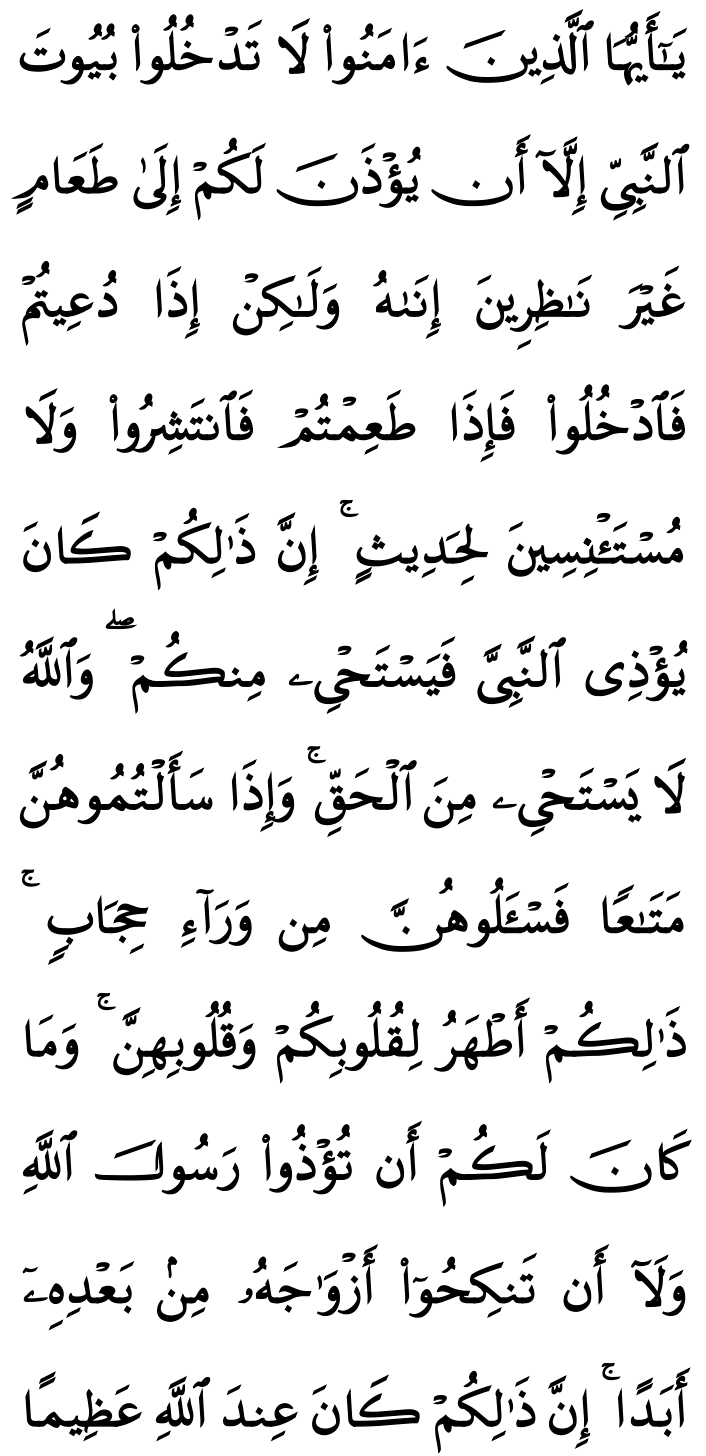

"Hai orang-orang yang beriman, janganlah kamu memasuki rumahrumah Nabi kecuali bila kamu diizinkan untuk makan dengan tidak menunggu-nunggu waktu masak (makanannya), tetapi jika kamu diundang maka masuklah dan bila kamu selesai makan, keluarlah kamu tanpa asyik memperpanjang percakapan. Sesungguhnya yang demikian itu akan mengganggu Nabi lalu Nabi malu kepadamu (untuk menyuruh kamu keluar), dan Allah tidak malu (menerangkan) yang benar. Apabila kamu meminta sesuatu (keperluan) kepada mereka (isteri-isteri Nabi), maka mintalah dari belakang tabir. Cara yang demikian itu lebih suci bagi hatimu dan hati mereka. Dan tidak boleh kamu menyakiti (hati) Rasulullah dan tidak (pula) mengawini isteriisterinya selama-lamanya sesudah ia wafat. Sesungguhnya perbuatan itu adalah amat besar (dosanya) di sisi Allah."

Asbabun Nuzul

Riwayat pertama ketika Rasulullah saw menikah dengan Zainab binti Jahsyin, beliau mengundang para sahabat menghadiri walimah. Setelah mereka makan dan minum terus santai bercakap-cakap, seolah beliau memberi isyarat seolah-olah akan berdiri, tetapi mereka tidak berdiri. Dan terpaksa Rasulullah saw berdiri meninggalkan mereka, sehingga sebagian dari mereka mengikutinya. Tetapi masih ada tiga orang yang masih asik bercakap-cakap. Setelah semua pulang Anas memberi tahu kepada Rasulullah, dan beliau pulang ke rumah Zainab. Anas mengikuti Rasulullah masuk ke rumah, kemudian beliau menutup hijab (penutup). Sehubungan dengan itu maka Allah menurunkan yata ke-53 dan 54 yang melarang masuk ke ruma Rasulullah saw sebelum mendapat izin. Demikian juga dilarang berlama-lama tinggal berada di rumah beliau. (HR Bukhari dan Muslim dan Anas).

Riwayat kedua Anas bin Malik pernah berkumpul dengan Rasulullah saw dalam satu rumah. Pada waktu itu Rasulullah saw masuk ke kamar pengantin wanita yang baru saja dinikahinya. Tetapi di dalam kamar banyak orang. Sehingga beliau kembalikeluar lagi. Setelah orang-orang pulang, barulah beliau 
masuk kamar dan membuat hijab antara beliau dan isterinya dengan Anas. Kejadian ini diterangkan oleh Anas kepada Abu Thalhah. Maka Abu Thalhah berkata: "Jika betul apa yang kamu katakan, tentu Allah akan menurunkan ayat Alquranyang berkenaan dengan masalah ini". Sehubungan dengan itu maka Allah menurunkan ayat ke-53 yang masyhur dengan ayat hijab. (HR Tirmidzi yang menurutnya adalah hadis Hasan, bersumber dari Anas).

Riwayat lain Ketika Aisyah sedang makan bersama Rasulullah, Umar bin Khatab masuk dan diajak sekalian makan bersama. Ketika itu jari Aisyah tersentuh tangan Umar, sehingga Umar berkata: "Aduhai sekiranya usulku untuk memasang hijab diterima, tentu tak seorangpun yang dapat melihat isterimu, wahai Rasulullah". Sehubungan dengan itu, maka Allah menurunkan ayat ke-53 sebagai ketentuan tentang hijab. (HR Thabrani dengan sanad yang Shahih dari Aisyah).

Pada suatu hari ada seorang lelaki yang datang pada Rasulullah dan berlama-lama ditempat duduk sehingga beliau keluar rumah sampai tiga kali agar orang tersebut mengkutinya keluar. Tetapi ia tetap tidak keluar. Ketika itu masuklah Umar bin Khathab dengan menunjukkannnya kebencian di muka lelaki itu. Ia berkata: "Wahai lelaki, barangkali kamu telah mengganggu Rasulullah". Rasulullah bersabda: "Aku sudah berdiri tiga kali agar ia mengikutiku. Akan tetapi ia tidak melakukannya". Maka Umar berkata: "Wahai Rasulullah, bagaimana sekiranya tuan membuat hijab. Sebab isteri tuan bukan seperti isteri-isteri yang lain. Hal ini akan menentramkan dan mensucikan hati mereka". Sehubungan dengan ayat itu, maka Allah swt menurunkan ayat ke-53 sebagai ayatul hijab (HR Ibnu Mardawih dari Ibnu Abbas). ${ }^{35}$

${ }^{35}$ A. Mujab Mahali, Asbabun Nuzul Studi Pendalaman al-Qur'an surah Al-Baqarah-An-Nas, (Jakarta, PT RajaGrafindo Persada, 2002), 685-686.
Ayat ini terkait dengan para isteri Nabi. Tidak ada isyarat baik secara eksplisit maupun implisit yang mengaitkan ayat ini dengan isteri orang-orang beriman secara umum. Menurutnya ada dua penjelasan pada ayat ini. Pertama Allah menceritakan bagaimana keadaan rumah nabi. Hal ini masuk kedalam wilayah kenabian (Maqom an-Nubuwwah) hal ini masuk dalam kategori pengajaran atau (ta'limat). Kedua ketika Allah mengharamkan orang-orang yang beriman untuk menikahi para janda Rasulullah. Hal ini masuk dalam kategori wilayah risalah (Maqom Risalah). ${ }^{36}$

Pada point pertama disebutkan 3 waktu dimana seseorang harus meminta izin ketika memasuki sebuah rumah seseorang, yaitu: Waktu tidur siang, Setelah waktu Isya' dan Sebelum fajar.

Ini adalah batas minimal untuk waktuwaktu yang tidak disukai seseorang jika ada orang lain masuk ke ruangannnya, karenanya yang disebut 3 waktu itu adalah aurat. Batasan maksimal adalah selalu meminta izin ketika masuk ruangan untuk setiap kali masuk ruangan. ${ }^{37}$

Point kedua ketetapan khusus yang berlaku bagi para isteri-isteri nabi bertujuan agar pihak lak-laki beriman berbicara kepada mereka dari balik hijab, padahal seluruh lelaki beriman tersebut adalah mahram bagi isteriisteri nabi,Allah telah menjelaskan bahwa ketetapan ini tidak diberlakukan pada perempuan mukminat pada umumnya sesuai firman-Nya: "Hai isteri-isteri nabi, kamu sekalian tidaklah seperti wanita lain, jika kalian bertaqwa. Maka janganlah kamu tunduk dalam berbicara sehingga berkeinginanlah orang yang ada penyakit dalam hatinya, dan ucapkanlah perkataan yang baik”. (QS.Al-Ahzāb [33]: 32).

Menurutnya Para perempuan mukminah tidak perlu mengikuti ketetapan yang khusus ditujukkan bagi para isteri nabi, maka hendaklah ia berbicara dari balik hijab dengan siapa saja, selain mereka yang disebut sebagai

\footnotetext{
${ }^{36}$ Muhammad Syahrur, al-Kitab wa al-Qur'an Qiro'ah Muassiroh, PDF 489.

${ }^{37}$ Muhammad Syahrur, al-Kitab wa al-Qur'an Qiro'ah Muassiroh, PDF 612.
} 
tujuh muharrim dan mereka yang termasuk kategori nisaihinna dalam ayat tentang alzinah (perhiasan). Sesungguhnya pengamalan ketetapan ini akan memberatkan diri sendiri dengan suatu beban yang tidak dibebankan oleh Allah pada hamba-Nya, karena ketetapan yang khusus berlaku bagi para isteri nabi adalah dalam hal berbicara dengan lelaki dibalik hijab.

Disamping itu, ketentuan bagi isteriisteri nabi ini tidak terkait dengan masalah perhiasan tersembunyi ataupun yang tampak pada diri mereka. Ketentuan yang sama-sama ditetapkan, baik bagi para isteriisteri nabimaupun bagi perempuan mukminah secara umum adalah dalam hal menjaga perhiasan tersembunyi dan cara pakaian yang disesuaikan dengan tuntunan tradisi dan situasi lingkungan, bukan dalam hal cara berbicara dari balik hijab. ${ }^{38}$

Menurut Muadudi Sebagimana para pendahulunya di abad pertengahan, ia menjelaskan bahwa ayat jilbab atau hijab pada surah al-Ahzāo ayat 53 menerangkan tentang pakaian Islam untuk perempuan mencakup penutup wajah dan sarung tangan. Persoalan tentang pakaian perempuan, termasuk penutup wajah (kecuali dalam keadaan darurat) mengarahkan ia pada pembelaan yang keras atas watak Islam. Bahkan kehidupan kaum wanita muslim pada zaman Nabi saw senantiasa mengenakan pakaian semacam itu, yang menunjukkan komitmen mereka terhadap jalan kehidupan yang benar. Menurut hukum-hukum Islam yang jelas dan rasional menetapkan bahwa perempuan muslim modern pun harus melakukan kewajiban itu. ${ }^{39}$

Menurut Sayyid Qutub ayat ini turun untuk mengajarkan orang-orang agar tidak masuk ke rumah Rasulullah saw tanpa izin.

\footnotetext{
${ }^{38}$ Muhammad Syahrur, Metodologi Fiqih Islam Kontemporer, Pnjm. Syahiron Syamsudin, Burhanudin (Yogyakarta, elSaQ Press, 2004), 523

${ }^{39}$ Barbara Freyer Stowasser, Reinterpretasi Gender Wanita dalam Al-Qur'an, Hadis, dan Tafsir,( Pustaka Hidayah), 332.
}

Jika mereka di undang untuk makan maka barulah mereka boleh memasukinya. Pada zaman modern ini kaum muslimin sangat membutuhkan adab seperti ini dimana banyak orang yang melupakannya bahkan meninggalkannya. Kemudian peringatan pada redaksi ayat ini Allah memerintahkan kepada siapapun agar jangan sampai menyakiti hati Rasulullah salah staunya dengan cara menikahi isteri-isterinya sesudah ia wafat karena hal tersebut merupakan dosa yang sangat besar. ${ }^{40}$

Dari ayat diatas dapat penulis ketahui bahwa ada dua point penting dalam pembahasan ayat ini. Pertama adab tentang bertamu bahwa etika dalam bertamu adalah:

1) Beri'tikad baik. Dengan awal yang baika akan terus menerus mendapatkan kenikmatan yang baik pula.

2) Tidak memberatkan tuan rumah.

3) Memilih waktu berkunjung. Hal ini sangat penting yang tadi telah dipaparkan di atas bahwa tamu harus memilih waktu berkunjung agar tidak menganggu tuan rumah.

4) Meminta izin kepada tuan rumah, sebelum bertamu hendaklah memberi kabar terlebih dahlu kepada tuan rumah apakah ada dirumah atau sedang diluar rumah.

5) Menyebutkan keperluan.

6) Segera kembali setelah selesai urusannya

7) Mendoakan tuan rumah

Point kedua perintah menutp aurat bagi perempuan. Ayat ini turun ketika rasulullah saw menikah dengan Zainab binti Jahsyi. Ayat ini di tunjukkan dan di perintahkan bukan hanya kepada isteri nabi akan tetapi kepada setiap wanita muslimah. Karena dalam hadis dikatakan "perempuan adalah aurat, jika ia keluar maka setan menyambutnya dengan hangat" maksud dari sanjungan setan pada

${ }^{40}$ Sayyid Qutub, Tafsir fi Zhilalil Qur'an, jilid 9. Pnjm As'ad Yasin dkk, (Jakarta, Gema Insani Press, 2004), 286. 
perempuan adalah menghiasinya dalam pandangan laki-laki.

Disinilah peran penting kaum perempuan untuk menjaga kehormatannya karena perempuan adalah makhluk yang diciptakan Allah sangat istimewa. Dengan menjaga amanah yang diberikan oleh Allah salah satunya dengan menutup aurat. Menutup aurat adalah sebuah kewajiban khususnya pada kaum perempuan. Karena wanita memiliki keistimewaan yang lebih dari laki-laki. Adapun manfaat dari menutup aurat adalah pertama menjaga diri kita dari dosa, kedua menghindari fitnah karena adanya pandangan negatif dalam surah Al-Nürayat 31 dijelaskan diharuskannya menjaga pandangan dari segala hal yang mengundangnya menjadi dosa. Ketiga dengan kita berusaha untuk menjaga pandangan, hal ini mencegah timbulnya hawa nafsu baik sesama maupun selain jenis. Keempat manfaatnya bukan hanya untuk jasmani dan rohani saja tapi baik juga untuk kesehatan. Karena dengan aurat terbuka bisa saja banyak penyakit yang menghampirinya misal kanker kulit, kulit menjadi hitam, flek hitam dikulit, dan masih banyak penyakit lainnya. Menutup aurat layaknya seperti permen. Jika peremen itu terbuka akan banyak lalat dan semut yang menghampirinya tapi apabila permen itu masih terbungkus rapih tidak ada yang berani mendekatinya. Hanya orang yang baik yang akan mendekatinya secara terhormat.

\section{b. SIMPULAN}

Penafsiran Muhammad Syahrur tentang teori limit, (Nazhariyat al-Hudud) khususnya pada pembahasan batasan aurat perempuan yang didasarkan pemahamannya terhadap Alqurandan asSunnah, penulis dapat mengambil kesimpulan bahwa teori limit Muhammad Syahrur (Nazhariyat al-Hudud) yang terkait dengan pakaian perempuan terbagi menjadi dua bagian: pertama batas maksimal (Had al-a'la) dan kedua batas minimal (Hadd alAdna). Dan Dalil-dalil hukum tentang batasan aurat perempuan dalam konsep berpakaian bagi perempuan adalah pada Qs Al-Nūr[24]:31, QS.Al-Ahzāb [33]:59 san Qs al-Ahzab[33]: 53. Menurut Muhammad Syahrur ada tiga ketentuan menurut terkait dengan pakaian perempuan:

a. Perempuan dilarang atau tidak di perbolehkannya terbuka (telanjang) kecuali hanya suaminya.

b. Batasan minimal perempuan secara umum menurutnya adalah menutup daerah intim bawah (al-Juyub asSufliyyah). Bagian ini disebut sebagai aurat berat (al-'Awrah al-Mughallazah). Bagian inlah yang harus ditutupi ketika berhadapan dengan orang-orang yang empat belas disebutkan di dalam surah Al-Nür31 pada tabel penjelasancdiatas. Dan menutup daerah intim atas (al-Juyub al-Ulmiyyah).

c. Pakaian untuk aktivitas dan bersosialisasi, ketentuannya berawal dari batas minimal kemudian disesuaikan dengan situasi dan kondisi masyarakat setempat. Batasan inipunmemiliki tingkatan-tingkatan hingga sampainya kepada batasa maksimal yang hanya memperlihatkan wajah dan kedua telapak tangan.

Konsekuensi perempuan yang menampakkan bagian al-Juyub menurutnya berarti ia telah melanggar Hudud Allah. Muhammad Syahrur berpendapat bahwa jilbab (kerudung) atau tutup kepala baginya bukan termasuk pada prinsip keislaman ataupun keimanan seseorang, melainkan hanya mengikuti kebiasaan masyarakat secara umum.

Dari ide-ide kontroversial Muhammad Syahrur tentang pemikirannya dalam kitab alKitab wa AlquranQiro'ah Muassirohmenjadi buah bibir di kalangan internasional dan banyak menuai pendapat pro-kontra

\section{DAFTAR PUSTAKA}

Abdurrahman, E. Risalah Wanita. Cet 6, .Bandung, Sinar Baru Algensindo Offest, 2005. 
al-Ashmawy, Muhammad Said. Hakikat Hijab wa Hujjiyat al-Hadits. Mesir: Madbuli as-Shagir, 1995.

Al-Khayyath, Muhammad Haitsam. Problematika Muslimah Di Era Modern, Pnjm Salafuddin Asmu'i. Jakarta: Erlangga, 2009.

Al-Maraghi. Tafsir Al-Maraghi. Pnjm. Anwar Rosyidi dkk.juz 22.Semarang: Putra Toha,tt.

Al-Sha'rāwi, Mutawalli. Fikih perempuan muslimah Busana dan Perhiasan, Penghormatan atas Perempuan, Sampai Wanita Karier. Cet 1. Pnjm Yessi HM. Basyaruddin. Penerbit Amzah, September 2003.

Hadits sembilan Imam, Riwayat Muslim no. 1467 PDF.

Mahali, A. Mujab. Asbabun Nuzul Studi Pendalaman Alquransurah alBaqarah-an-Nas, .Jakarta: PT Raja Grafindo Persada, 2002.

Nur Lailatul Musyafa'ah, "Pemikiran Fikih Wanita Qasim Amin”, (Jurnal JS GI, Vol 04, No. 01, Agustus 2013 ISSN: 2087-983).

Qutub, Sayyid. Tafsir Fi Zhilalil Qur'an dib bawah naungan Alquran(surat Tahaa 57-An-Naml 81), Jilid 8. Pnjm As'ad Yasin, dkk. Jakarta:Gema Insani Press, 2004.
Tafsir fi Zhilalil Qur'an, jilid 9. Pnjm As'ad Yasin dkk. Jakarta, Gema Insani Press, 2004.

Sabiq, Sayyid. Fikih Sunnah 9, Ahli Bahasa Mohammad Nabhan Husein, Cet 20. Bandung: PT Alma'arif, 2003.

Shihab, M Quraish. Tafsir al-Misbah (Pesan, Kesan dan Keserasian al-Qur'an), volume 8, cet V .Jakarta: Lentera Hati, 2002.

Stowasser, Barbara Freyer. Reinterpretasi Gender Wanita dalam al-Qur'an, Hadis, dan Tafsir. T.k. Pustaka Hidayah,t.t.

Syahrur, Muhammad. al-Kitab wa AlquranQiro'ah Mu'assiroh, PDF . .Epistimologi Qur'an Tafsir Kontemporer ayat-ayat Alquranberbasis Materialisme-DialektikaHistoris, Cet 2. Pnjm M Firdaus.Bandung:Penerbit Marja, 2015. .Metodologi Fiqih Islam Kontemporer, Pnjm. Syahiron Syamsudin, Burhanudin .Yogyakarta :elSaQ Press, 2004. 